Article

\title{
The Analysis of Urban Fluvial Landscapes in the Centre of Spain, Their Characterization, Values and Interventions
}

\author{
Pedro Molina Holgado ${ }^{1}$, Lara Jendrzyczkowski Rieth ${ }^{2}$, Ana-Belén Berrocal Menárguez ${ }^{3, *}$ and \\ Fernando Allende Álvarez ${ }^{1}$ (1) \\ 1 Departamento de Geografía, Universidad Autónoma de Madrid, 28049 Madrid, Spain; \\ pedro.molina@uam.es (P.M.H.); fernando.allende@uam.es (F.A.Á.) \\ 2 Programa de Pos Graduação em Engenharia Civil: Construção e Infraestrutura, Universidade Federal do Rio \\ Grande do Sul, Porto Alegre-RS 90040-060, Brazil; larart.arq@gmail.com \\ 3 Departamento de Ingeniería del Transporte, Territorio y Urbanismo, ETSI Caminos, Canales y Puertos, \\ Universidad Politécnica de Madrid, 28040 Madrid, Spain \\ * Correspondence: anabelen.berrocal@upm.es
}

Received: 5 May 2020; Accepted: 29 May 2020; Published: 7 June 2020

\begin{abstract}
River areas are undoubtedly among the most valuable territorial areas in Europe, not only in terms of their eco-landscape and use but also, culturally. However, there is currently a sharp reduction in the extension and increase of deterioration of riverbanks around the world. A substantial part of losses and deterioration are associated with the artificialization of the territories, derived mainly from a less than respectful urbanization around these landscapes. Urban and peri-urban riverbanks are landscapes in expansion due to the continuous growth of built-up spaces. Therefore, they should be areas of preferential consideration, especially in territories with a marked tendency to dryness, like the centre of the Iberian Peninsula. This article aims to contribute to our understanding of these spaces through the study of four distinct cases in the centre of the peninsula, in particular: the river Manzanares running through the city of Madrid, the river Tagus in Toledo and running through Talavera de la Reina, and the river Henares in Guadalajara. Three of the four urban water courses analyzed are zones of special interest for waterfowl: they sustain a winter population that varies between 745 and 1529 birds and they provide a home to some globally threatened species. The density of the riparian birds is also very high during winter, these values oscillating between a mean of 141.16 and 240.12 birds/10 ha. It should be noted that the diversity of this group of birds in the four regions studies is also high $(\mathrm{H}>2.4$ nats). The article also examines the interventions and the urban planning criteria applied to these urban and peri-urban river spaces, inferring the need to reassess urban planning in river areas to ensure it is compatible with their operation, values and possible uses.
\end{abstract}

Keywords: urban rivers; urban planning; cultural landscape; natural landscape; waterfowl; riparian birds

\section{Introduction}

River landscapes are among those most affected by human intervention around the world [1-4], especially in historically longstanding urban areas where their alteration dates back many centuries [5]. All over the planet, rivers and their associated landscapes have been affected by intense fragmentation processes, which cause significant simplification and a loss of connectivity. This circumstance limits the river's ability to flow uninterrupted and it affects many of their fundamental processes and functions. Accordingly, it produces a rapid decline in biodiversity [6] and in essential ecosystem 
services [7]. Moreover, the occupation of areas near riverbanks by infrastructures often intensifies these processes [8].

River areas are very valuable areas in terms of their use and ecology, as well as culturally [9-12]. Indeed, riverbanks are considered to be the most diverse, dynamic, and complex terrestrial habitats on earth [13], and to be true accumulators of history. Like all landscapes, riverbanks are laden with objective and subjective value, derived from the elements they contain and from the cultural references they have accumulated [14]. These values are typical of the most natural spaces that are well-preserved and only sporadically affected by human pressure. However, they are also characteristic of other less well valued river areas, such as those located in areas that have received intense intervention and that have been modified most significantly by human activity, the greatest example of which are probably urban areas.

Urban river spaces, like other green areas and free spaces within cities, sustain species of fauna and flora typical of non-urbanized environments [15], sometimes even rare or globally threatened species [16]. The presence of these elements often reflects the complexity of these spaces, as well as bearing witness to the persistence of natural remnants [17-19] and the density of the vegetation [20]. In terms of biodiversity, riverbanks are areas of particular interest, although except for some groups of vertebrates like birds [21-24], their potential has not been widely explored [25,26]. However, river ecosystems are also very vulnerable to invasion by non-indigenous species [27], the presence of such exotic species generating problems for the conservation of biodiversity [28].

Although rivers and their banks are areas of special value, their proximity or position within the built-up space generates multiple problems and tensions [29], which are generally associated with a reduction in their area and the loss of specific values (environmental, territorial, landscape, and cultural). In particular, the impact of human activities produces a significant homogenization and a reduction of riparian vegetation [30], as well as reducing their possibilities to serve as spaces for public use. Their conservation is justified for diverse reasons, including the preservation of local biodiversity, the creation of transitional territories and areas of extra-urban habitats, or to understand and facilitate responses to climate change [31].

The marked reduction in the extension of riverbanks is a widespread global process and it is evidence of their deterioration. There have been very intense losses of this type of landscape in Europe, with an estimated decrease of 12\% (7508 ha) during the period 1987-2000. In Spain, this has affected more than 2 million hectares, which represents approximately $4 \%$ of the Spanish territory [32]. A substantial part of these losses are associated with the artificialisation of these territories, mainly derived from disrespectful urbanization of these landscapes [33]. In this sense, urbanization currently represents the most relevant territorial action on the planet. In Europe, where $74 \%$ of the population lives in urban areas [34], the extent of urbanization is quite dominant. Indeed, Spain has experienced significant urban concentration in the 20th century [35], generating extensive and dense metropolitan areas such as the administrative region of Madrid. This metropolitan area is the third largest in the European Union in terms of the number of inhabitants, after Paris and London [36,37].

The continuous expansion of urban areas ultimately increases the extension of urban riverbanks. These spaces are in many cases areas of risk that are difficult to integrate into the urban fabric due to their configuration, characteristics, and hydrological and geomorphological nature. They are also commonly areas of marginal use, often occupied by less-favoured social groups, living in substandard houses on the river banks, and they are essentially residual spaces in part due to the threat and risk posed by periods when the rivers are in full flow. In Spain, they have been, and still are, territories separated from urban spaces in our minds, often existing at the limits of those urban spaces and with no specific public use. Thus, they are poorly integrated in the best-case scenario, and often completely abandoned. These circumstances have led to the non-formal occupation of flood plains in urban and peri-urban areas [38], causing a marginal and often private use of these public spaces. In Spain, the limited connection between the cities that border the rivers that flow through them has, in most cases, generated strong social detachment [39]. This phenomenon is almost certainly associated with 
the perceived risk traditionally posed by proximity to river courses, which has traditionally manifested itself in neglect and degradation of the fluvial territory, and its poor integration into the urban fabric. To mitigate the impact of this situation, it would be useful to integrate societal considerations into the management models of these spaces, as occurs in some river reserves in Europe and the United States [40].

The tensions and threats that affect these spaces are also related to the profound alteration of river systems, most notably, the poor water quality, the loss of water resources, the morphological alteration of rivers, and modifications to the hydrological and hydraulic characteristics of the river course. Water is the driving force upon which the operation of river systems depends, and the changes to the hydrological and hydraulic behaviour of river courses in central Spain have been quite intense [41]. One example is the River Tagus that passes through the city of Toledo, where the average annual flow contribution at the Toledo gauging station fails to reach $40 \%$ of the estimated contribution in a natural regime $\left(3256.93 \times 10^{6} \mathrm{hm}^{3}\right)$ [32], a value that decreases to $29.1 \%$ in the latest available data for the hydrological year 2008-2009 [42].

The reduced flood risk in the centre of Spain has favored occupation of the flood plains associated with river courses in urban areas, as well as the alteration of canals. In general, the environmental and landscape value of these areas has generally diminished [43]. However, river spaces are also areas of clear opportunity that must be properly considered, understood, and managed in urban and territorial planning, both locally and regionally. This is particularly relevant in terms of public use, intervention, landscape recovery, and conservation of environmental diversity. In Spain, fluvial territories in general, and the urban river territory in particular, are largely public land integrated into the Public Hydrological Domain (which governs the public water supply).

Despite the intense occupation of these areas, there are often semi-natural remnants lying between infrastructures that are little occupied. Riverbanks are also key areas for the conservation of environmental and landscape diversity, as indicated by the European Biodiversity Strategy [44] or the European Landscape Convention [45], with significant environmental value and potential and, in general, with a strong potential for regeneration, even in the case of heavily intervened banks. They are undoubtedly key spaces for the recovery of ecological, landscape, and territorial connectivity, in the sense specified in the EU Strategy on Green Infrastructure [46], and they are easy to recover through low-cost interventions. In Spain, urban riverbanks, like all riverbanks, fall under a specific regulatory framework for water courses and fluvial territories [47], which clearly provides legal protection for many actions, especially those carried out under the governance of the Public Hydrological Domain.

\section{Materials and Methods}

This study analyzes and assesses the treatment given to stretches of four Spanish rivers in four projects that specifically centred on those fluvial territories. An environmental characterization of the study areas was initially performed, considering the value of each area for waterfowl and riparian birds during the winter 2019-2020, and also the general structure of the landscape and the presence of habitats included in Annex I of the Directive 92/43. This characterization allows us to assess the impact of the projects undertaken by applying objective criteria, and to estimate their potential impact while they are still in the design phase.

\subsection{Study Area}

The four stretches of urban river (Figure 1, Table 1) selected for study were situated in the Tagus Hydrographic Basin on the banks of the rivers Manzanares, Henares, and Tagus, lying in the provinces of Madrid and Castilla-La Mancha (Central Spain). These four river sections were chosen based on our interest in analyzing comparable urban river spaces in similar or assimilable landscape contexts, which are also representative of the characteristic of the urban river landscapes in central Spain (Figure 2). All the cases analyzed are situated in the same climatic (Continental Mediterranean) [48] and 
morphostructural context (Tertiary Sedimentary Tagus Basin or Madrid Basin) [49], passing through large (Madrid) or intermediate cities (Guadalajara, Toledo, and Talavera) that are representative of the different urban and demographic configurations and dynamics in Central Spain [50]. The rivers analyzed are courses of different hydrological entities that are subject to disparate regulation at their headwaters, as already indicated, and all are integrated into the Tagus Hydrographic Basin.

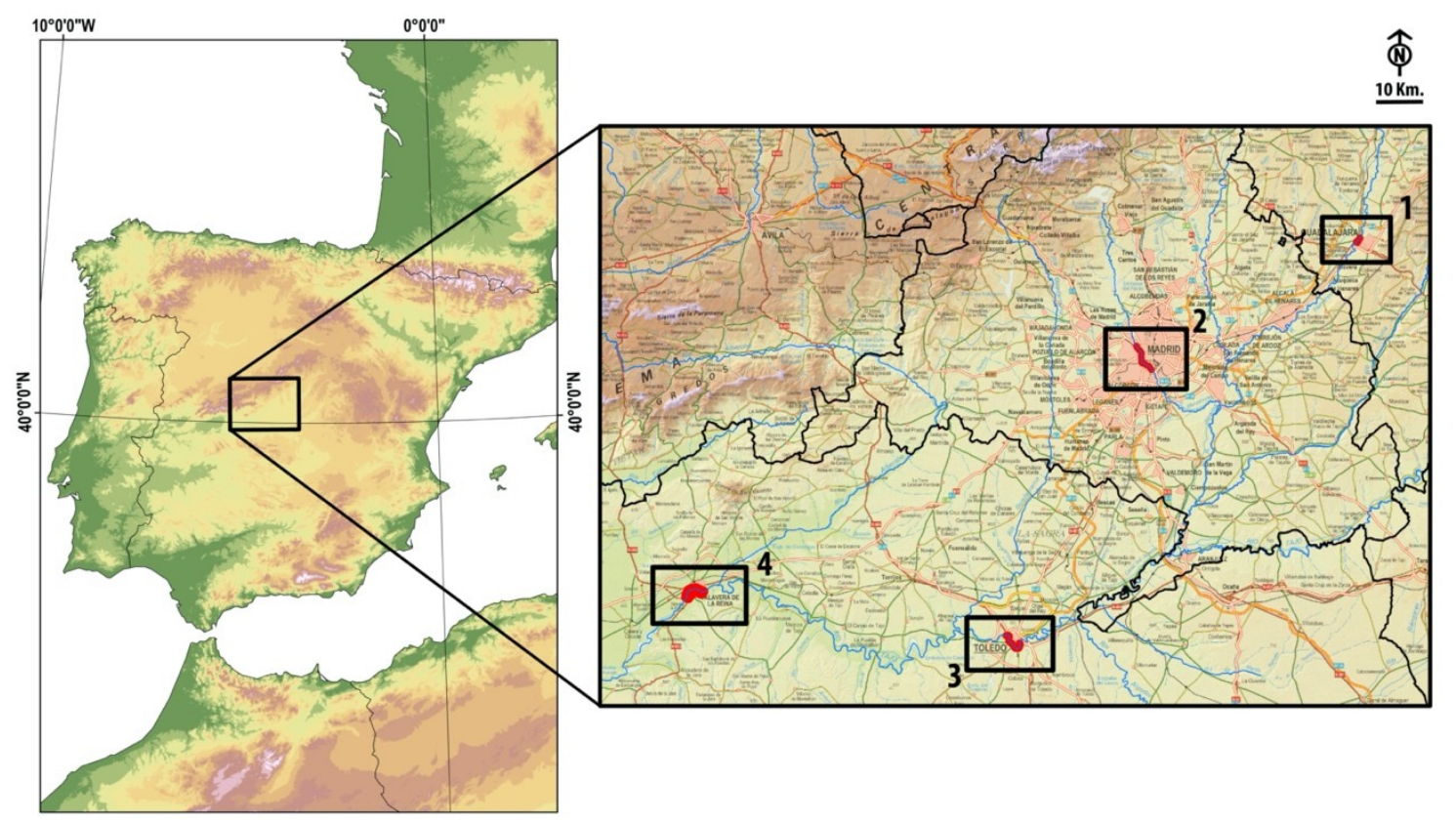

Figure 1. Location of study areas. 1. Henares (Guadalajara); 2. Manzanares (Madrid); 3. Tagus (Toledo); and 4. Tagus (Talavera de la Reina).

Table 1. Basic characteristics of the river stretches analyzed. Source: demographic information [51], hydrological data [43].

\begin{tabular}{|c|c|c|c|c|c|}
\hline River & $\begin{array}{l}\text { Length of Stretch } \\
\text { Analyzed (km) }\end{array}$ & City & $\begin{array}{l}\text { Population } \\
2019\end{array}$ & Region & $\begin{array}{c}\text { Annual } 10^{6} \mathrm{~m}^{3} \\
(1987-2008)\end{array}$ \\
\hline Manzanares & 6.86 & Madrid & $3,266,126$ & Madrid & 66.92 \\
\hline Henares & 1.47 & Guadalajara & 85,871 & \multirow{3}{*}{$\begin{array}{l}\text { Castilla-La } \\
\text { Mancha }\end{array}$} & 291.13 \\
\hline Tagus (Toledo) & 4.56 & Talavera & 84,417 & & 1338.26 \\
\hline Tagus (Talavera) & 6.36 & Toledo & 84,873 & & 1126.05 \\
\hline
\end{tabular}




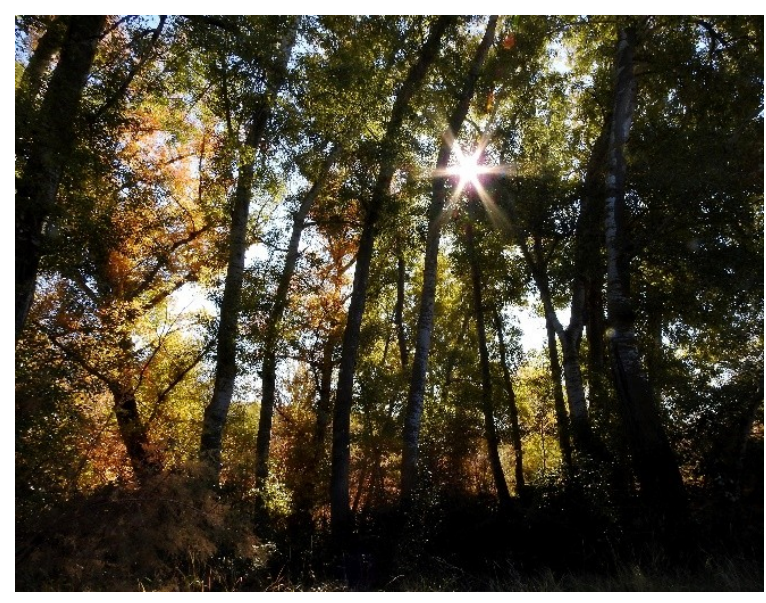

(a)



(c)



(b)

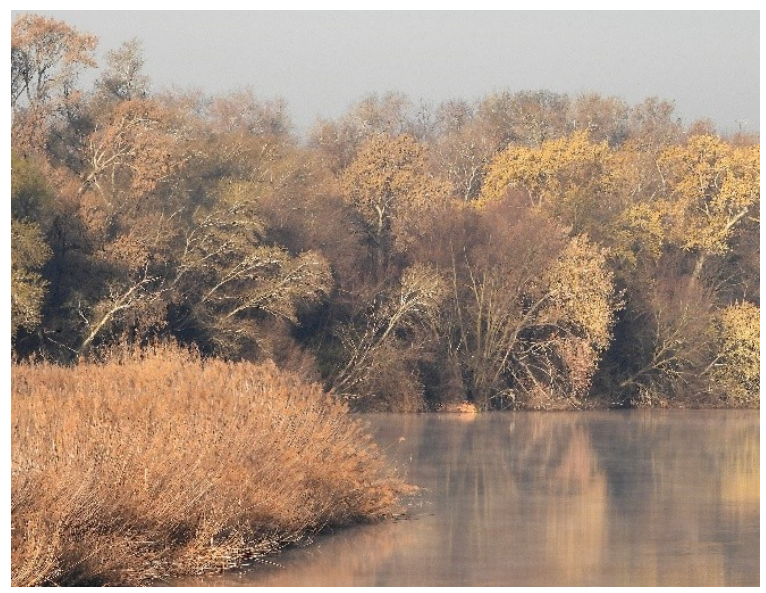

(d)

Figure 2. The rivers analyzed. Upper left, (a) Populus alba forest on the Henares river (5/12/2017). Upper right (b), the Manzanares river channel at the Segovia Bridge (14/1/2020). Lower left (c), the Tagus river in Toledo at the level of the "Artilleros" dam (16/1/2018). Lower right (d), a mixed forest of Populus alba and Salix alba on the Tagus river in Talavera de la Reina (25/2/2020).

\subsubsection{River Manzanares in Madrid}

The stretch of the river Manzanares chosen for study was a $6.86 \mathrm{~km}$ urban section channelled over $5.57 \mathrm{~km}$ and limited by a breakwater over $1.29 \mathrm{~km}$ after intense intervention from 1946 [52]. Associated with this canalisation, 9 small dams were built that transformed the river into a succession of bound water canals, thereby eliminating sections of rapid-flow. After the opening of the dams, the canalisation of the river course has become the main reason for the loss of its natural aspect, as well as provoking alterations to its hydrological and hydraulic characteristics. The closest gauging station is located $7 \mathrm{~km}$ upstream from the starting point of the river stretch studied, where an average annual contribution of $66.92 \times 10^{6} \mathrm{~m}^{3}$ was recorded (1987-2008). The last gauging station is situated $19.6 \mathrm{~km}$ downstream of the southern limit of the study area, where the Manzanares reaches $410.12 \times 10^{6} \mathrm{~m}^{3}$ after receiving only $4.9 \times 10^{6} \mathrm{~m}^{3}$ from the "Culebro" stream or arroyo. This increase, six times higher than the contribution of the river in the city of Madrid, is due to water discharge from the city and the sanitation system in its immediate metropolitan area. In the section studied, the river lacks forest and riparian vegetation on its banks as it borders urbanized or landscaped areas. There are also nineteen footbridges and four historical bridges: the Queen Victoria (1908-1909), King's (1815-1816), Segovia (1574-1577), and Toledo 
(1715-1722) bridges [53]. After the completion of the "Madrid Río" landscaping project, the whole section became an area of intense recreational use.

\subsubsection{River Henares in Guadalajara}

A $1.47 \mathrm{~km}$ urban stretch of the river Henares in the city of Guadalajara was studied. This section was very well preserved until 2019, protected on its entire left bank by a continuous embankment that separates the free zone of the river from the urban territory. Both riverbanks are occupied by an authentic Populus alba forest, a habitat included in Annex I of Directive 92/43/EC. There are no structures spanning this section, which today is an urban park. Unlike the section studied, the river sections located outside the limits of the Guadalajara municipality, upstream and downstream, are included in the ZEC Ribera de Henares ES4240003 [54], all of which share similar values. The average annual contribution at the closest gauging station reaches $29.12 \times 10^{6} \mathrm{~m}^{3}$.

\subsubsection{The River Tagus in Toledo}

The urban river section studied was a $6.36 \mathrm{~km}$ stretch, open in sedimentary materials, and partly embedded in granitoids, leukogranites, and pegmatites (Carboniferous-Paleozoic) [55]. The entire riverbank maintains a narrow and discontinuous canopy of Populus alba, Populus nigra, Salix alba, Tamarix africana, and Tamarix canariensis, a habitat included in Annex I of Directive 92/43/EC, as well as dense masses of marsh vegetation (Phragmites australis and Typha domingensis). There are remains of 14 water mills preserved along this section, some originating from the 9th century [56], and seven weirs that reduce the course of the river to a slow flow. There are river islands of great interest downstream of three of the weirs, one a refuge to an interesting heron colony (Ardea cinerea, Bubulbus ibis, and Nycticorax nycticorax). There are five bridges along this stretch of the river, including the historical bridge of "Alcántara" (of Roman origin but rebuilt in the 10th century) and the bridge of San Martín, for which an exact date of construction has not been established but that was cited as long ago as 1165 [57]. The average annual hydrological contribution in the section is $1126.05 \times 10^{6} \mathrm{~m}^{3}$ for the period 1987-2008. The entire stretch analyzed is a space used intensely by the local population for recreational activities and also, by a significant number of visitors since Toledo is a World Heritage City [58] (913,796 overnight stays in 2019) [59].

\subsubsection{The River Tagus in Talavera de la Reina}

The section studied here is a $4.56 \mathrm{~km}$ urban and peri-urban stretch that houses four weirs, which reduce the flow of the river to predominantly slow. The urban façade occupies $2.95 \mathrm{~km}$ of the right bank and $565.2 \mathrm{~m}$ of the left bank. There is intense recreational activity on both margins, a historic pedestrian bridge (Puente Viejo "the Old Bridge", XIII century) [60], and three bridges for vehicles along this section. The section houses two large islands (47.65 ha, $66.47 \mathrm{ha})$, on which $35 \%$ of their surface area is covered by alluvial forests and mosaic forests, dominated by Populus alba, Populus nigra, Salix alba, Tamarix africana, and Tamarix canariensis, and structured into three large groves (18.34 ha, $14.98 \mathrm{ha}$, and $6.8 \mathrm{ha}$ ). The remaining $65 \%$ ( $74 \mathrm{ha}$ ) is covered by open woodland (tree density $\leq 25 \%$ ), pastures of diverse nature, and masses of marsh vegetation. The banks of the bankfull channel maintain a meagre arboreal-arborescent canopy made up of the aforementioned species.

\subsection{Data Collection from the Natural Environment}

The analysis of the natural environment provides data from the wintering waterfowl and forest-marsh communities, as well as the basic structure of the vegetation. Monthly censuses were carried out between December 2019 and February 2020 to study the bird communities. The censuses of forest-marsh birds was carried out using "census itineraries" [61], with a main counting strip of $25+25 \mathrm{~m}$, the results of which are expressed as global numbers (abundance, a), number of species (richness, r), and birds/10 ha (density, d). Waterfowl censuses are global counts performed in accordance with the "field protocol for water bird counting" [62], expressed as the global figures (abundance 
a: total number of waterfowl; richness $\mathrm{r}$ : number of species) or as birds per $\mathrm{km}$ of river (density $\mathrm{d}$ : birds $/ \mathrm{km}$ ). The length of the stretches examined did not extend over the entire river sections analyzed, except for the river Manzanares, whereas the waterfowl censuses did cover the entirety of the sections (Table 2). The diversity of the communities is calculated according to the Shannon index [63] (H), using a Napierian logarithm (expressed in nats). The values of abundance and density in the different zones were compared using a Kruskall-Wallis Test (K). To only compare two series of values, a Kolmogorov-Smirnov (D) Test was used in the case of independent samples and a Student $t$-test $(\mathrm{t})$ for paired simples. The Statgraphics Centurion 18(C) software and Microsoft Excel 2016@ were used to manage the data and to perform the aforementioned tests.

Table 2. Characteristics of the census sections.

\begin{tabular}{cccc}
\hline River & $\begin{array}{c}\text { Length of the Waterfowl } \\
\text { Section Analyzed } \mathbf{( k m )}\end{array}$ & $\begin{array}{c}\text { Length of Riparian Bird } \\
\text { Section Analyzed (km) }\end{array}$ & $\begin{array}{c}\text { Riparian Bird Area } \\
\text { Analysis (ha) }\end{array}$ \\
\hline Manzanares & 6.86 & 6.86 & 34.31 \\
Henares & 1.47 & 1.47 & 7.35 \\
Tagus (Toledo) & 6.36 & 4.23 & 21.15 \\
Tagus (Talavera) & 4.56 & 1.18 & 5.90 \\
Total & 19.25 & 13.74 & 68.71 \\
\hline
\end{tabular}

For each species, its Status and SPEC Category in Europe is indicated, and the categories recognized in the study area were [64]:

European Population Status Category [65]:

- Vulnerable (VU), European population meets any of the IUCN Red List criteria for VU.

- Near Threatened (NT), European population close to meeting the IUCN Red List criteria for VU.

- Declining, European population has declined by $\geq 20 \%$ since the 1970 s (when the Birds in Europe series began), and has continued to decline since 2001.

- $\quad$ SPEC Category (Species of European Conservation Concern):

- $\quad$ SPEC 1, European species of global conservation concern, i.e., classified as Critically Endangered, Endangered, Vulnerable, or Near Threatened at global level [66].

- SPEC 2, Species whose global population is concentrated in Europe, and which is classified as Regionally Extinct, Critically Endangered, Endangered, Vulnerable, Near Threatened, Declining, Depleted, or Rare at European level [67].

- $\quad$ SPEC 3, Species whose global population is not concentrated in Europe, but which is classified as Regionally Extinct, Critically Endangered, Endangered, Vulnerable, Near Threatened, Declining, Depleted, or Rare at European level [67].

The species included in Annex I of the Directive 2009/147/EC (Birds Directive) are also cited [68], "Those that shall be the subject of special conservation measures concerning their habitat in order to ensure their survival and reproduction in their area of distribution." (Article 1.4). To determine the structure of the vegetation and the landscapes, a basic analysis was carried out to identify 16 categories.

- Water areas.

- Sandbanks and water cover.

- Rockfill/sandbanks with scattered trees.

- Marsh vegetation: dense masses of Typha domingensis, Phragmites australis, at times with Schoenoplectus lacustris, often accompanied by hygrithrophilous species (Rumex cristatus, Rumex crispus, Polygonum persicaria, and Polygonum lapathifolium).

- Sandbanks with marsh vegetation.

- Wooded areas: arboreal-arborescent groves and canopies with at least $40 \%$ coverage, dominated by Populus alba, Populus nigra, Salix alba, and Tamarix canariensis, sometimes with 
Tamarix africana, Fraxinus angustifolia, Salix purpurea, and Salix salviifolia. Allochtonous or hybrid elements often appear (Platanus $\times$ hybrida, Robinia pseudoacacia, Gleditsia triacanthos, Ailanthus altissima, Ulmus pumila, Populus $\times$ canadensis, and Eleagnus angustifolia).

- Wastelands: areas occupied by herbaceous vegetation, from hygrophilous to mesophilic, sometimes nitrophilous, with or without wooded areas (coverage $\leq 10 \%$ ). Among many other communities they include grassland-rushes of Scirpoides holoschoenus, pastures of Brachypodium phoenicoides-Elymus pungens, hygrithrophilous pastures (Rumex cristatus, Rumex crispus, Polygonum persicaria, and Polygonum lapathifolium), and many ruderal communities dominated by Gramineae, Brassicaceae, or Asteraceae.

- Rocky areas.

- Mosaic of wooded areas and marsh vegetation.

- Mosaic of wooded areas and wasteland: a mix of dense wooded areas and wastelands.

- Mosaic of scattered trees and wasteland: mixture of low coverage wooded areas (40-10\%) and wastelands.

- Mosaic of scattered trees and marsh vegetation: mixture of low coverage wooded areas $(40-10 \%)$ and marsh vegetation.

- Mosaic of scattered trees and rocky areas.

- Garden areas.

- Artificial land.

- Gravel pits: (extraction of aggregates and sand).

These areas were defined by a buffer of 200 meters on each side of the central axis of the channel, which in the case of a canalized channel was adjusted to the canalised banks (i.e., river Manzanares). Within this buffer the land use was photointerpreted, generally involving the area of the floodplain nearest to the main channel. This process was carried out on the 1:5000 orthophotographs obtained as part of the Spanish National Plan of Aerial Orthophotography by the National Geographic Institute, available in ECW file format from 2012. The information was coded on the basis of the estimated proportion of the covered space dedicated to each use, differentiating a total of 16 categories, where single-use or mosaic polygons were also contemplated. The ArcGis 10.5 (C) software was used to perform digitization, coding, and topological validation, and to produce the shapefile format for the layer of results obtained (Figures A1-A4).

The habitats included in Annex I of Directive 92/42/EC [69] were also considered for each study area.

\subsection{Project Reviews}

In the case of the work carried out between 2016 and 2019 on the river Manzanares in Madrid, the plan for Naturalization of the Manzanares as it passes through the city of Madrid was examined [70], while some complementary field work was also carried out. In the case of Toledo, the initial document of the Environmental Impact Assessment for the project to integrate the river Tagus into the city of Toledo was examined [71]. The information analyzed in the study of the River Henares in Guadalajara came from the city's Strategy for Sustainable Urban Development [72], which was complemented by field work as the project is currently being carried out. Finally, for the actions proposed in Talavera de la Reina, the report and plans that form part of the technical proposal that adjudicated the project following the international call for ideas were consulted [73]. In addition, abundant auxiliary information was evaluated, such as news reports in the press, debate forums, consultations with the European Parliament, etc. [74-76]. A synthesis of the collected data is available in Appendix B. 


\section{Results}

\subsection{Analysis of the Cases}

In May 2016, the Madrid City Council began to implement the measures included in the "Plan for Renaturalization of the River Manzanares as it passes through the city of Madrid." This was a plan based on the proposal that the group "Ecologists in Action" sent to the City Hall in January of that same year. The measures undertaken did not involve large construction work and no new structures were built (Table A1). The techniques employed in the canals were based on bioengineering principles, which involve using natural materials or those that are biodegradable in the short or mid-term.

The Integrated Strategy for Sustainable Urban Development of the municipality of Guadalajara was approved in December 2016, and it included a set of actions aimed at, "Recovering the land occupied by the right bank of the River Henares from the neighborhood of 'Los Manantiales' to the 'Finca de Castillejos' [72]." Under this undefined objective, "Recovery" work on the right bank of the river Henares, between the "Arab bridge" and the "Julián Basteiro bridge" was proposed and executed. Among the work undertaken, urbanization and gardening actions were implemented under the auspices of the Public Hydrological Domain between October 2018 and May 2019 (Table A2). This work, with a total cost of $€ 1,438,277.90$, was $80 \%$ co-financed by the European Regional Development Fund. According to various publications in the media, the action implemented is far from that indicated in the application submitted to the European Union for co-financing, in which the main objective was the environmental recovery of the river Henares and the increase in its biodiversity. In this sense, on 25 October 2018, the Equo European parliamentarian, Florent Marcellesi, registered two questions in the European Parliament related to the legitimacy of the actions undertaken with the co-financing of ERDF funds. In December of the same year, the Parliament responded by stating that, "According to the Spanish authorities, the project implemented by the City Council received authorization from the Tagus Hydrographic Confederation, yet it does not currently meet the requirements necessary to obtain EU funding". At the time this response was registered, the works were fully underway, and the site had put up a sign indicating the European co-financing received.

The notification by the Tagus Hydrographic Confederation of the results of the "International Call for Ideas and Projects aimed at integrating the river Tagus into the city of Toledo," presided over by a panel of judges, took place in December 2009 (BOE no. 289, 1 December, 2009). However, it was not until 2014 that the project chosen was released into the public domain [71]. The project proposed an extensive, intense, and ambitious program of actions along $43 \mathrm{~km}$ of the river's course as it runs through the municipality of Toledo. However, it is in the urban section of the city of Toledo where the project is most intense, in part due to the profound modifications to the existing configuration of the river's course, considering the implementation of important interventions, such as earth movements and the construction of concrete structures (Table A3).

The final criterion to define the appropriate actions was to protect this space against floods over a 100-year return period, with reference to other considerations like the volume of earth filling required or the degree of transformation of the current environment. Likewise, the landscape relevance in the intervention was prioritized over its integration into the environment, as witnessed by the choice of the geometry of the river walk, which was built using concrete flagstones with an angular broken geometry that will intentionally be perceived as a clearly artificial and autonomous element of the landscape [71]

In January 2018, the Tagus Hydrographic Confederation unveiled the winning proposal in the "International Call for Ideas and Projects aimed at recovering the banks of the rivers Tagus and Alberche in the municipality of Talavera de la Reina." It was the so-called "When the river sounds" ("Cuando el río suena") idea, submitted by a temporary union of three architectural and engineering consultancy companies [73]. The action proposed covers an extended stretch of the river, from the mouth of the river Alberche to the natural site known as the "Charca del Cura", passing through the urban section of the city of Talavera. The actions are quite diverse in nature and scope, depending on the proximity to 
the urban nucleus, although in general terms they involve a permeation of flow towards well-preserved river spaces that are currently difficult to access (Figure 3, Table A4).

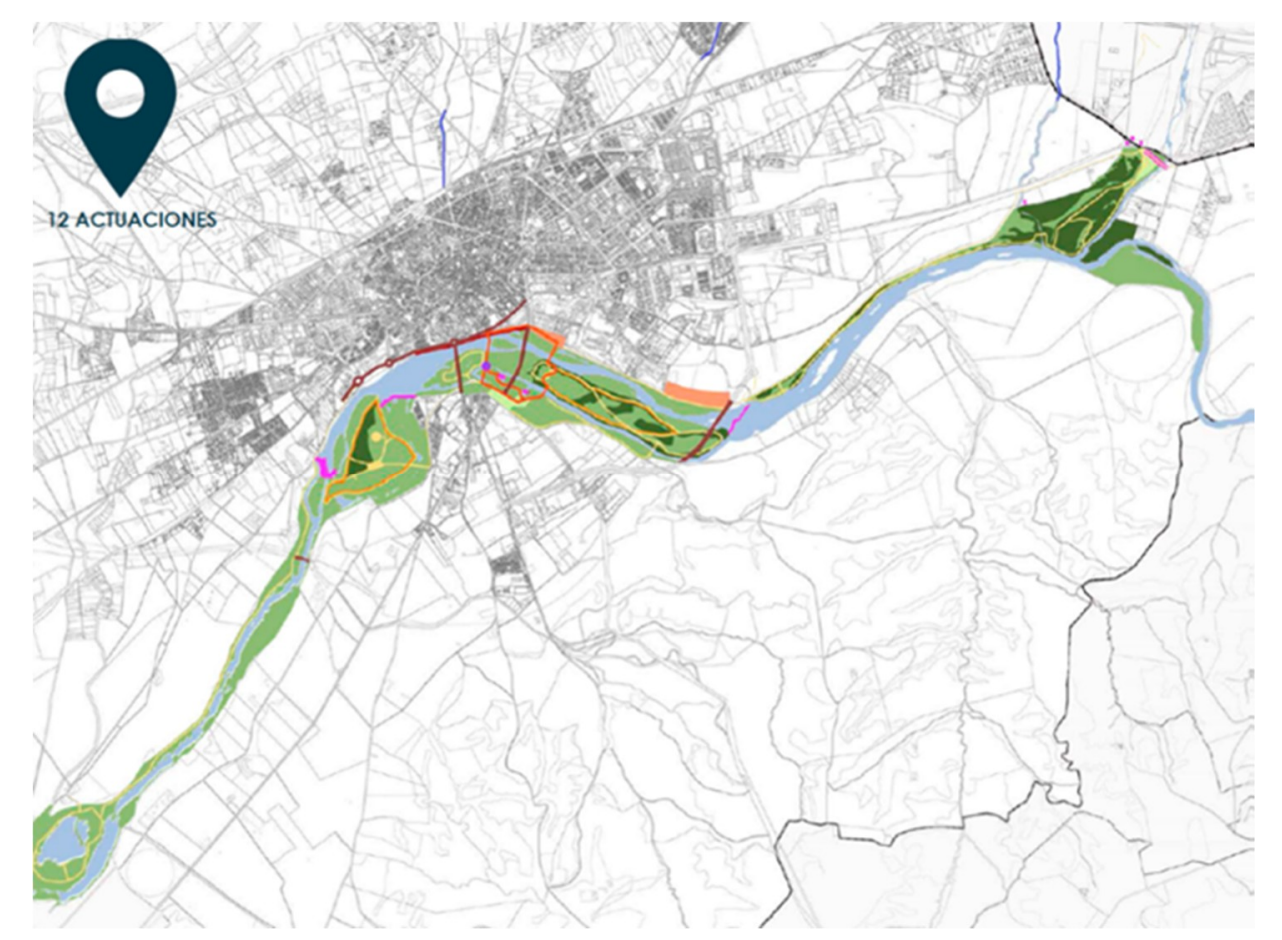

Figure 3. Interventions proposed in the planned rehabilitation project for the riverbanks and islands of the river Tagus in Talavera de la Reina [73].

\subsection{Basic Structure of the Landscape}

When the 16 landscape categories identified were considered (Appendix A), the river landscape at the four study areas did not show significant differences $(K=4.57 ; p>0.05)$. The landscape of the Tagus river bank in Talavera was the most diverse $(\mathrm{H}=1.95)$, followed by that of the river Henares $(\mathrm{H}=1.83)$, of the river Tagus in Toledo $(\mathrm{H}=1.59)$, and finally, that of the river Manzanares $(\mathrm{H}=0.83)$. Nevertheless, all have low values of diversity.

Due to its structure and composition, the landscape of the river Manzanares as a whole differs from the other river landscapes analyzed, with the proximity between the two sections of the river Tagus representing the maximum. In the river Henares, landscaped and artificial surfaces occupy a large area $(49 \%)$, along with wooded areas (20\%). The wooded areas, in their different categories, are precisely the larger areas in the two sections of the river Tagus analyzed. The river Manzanares is quite different to the other river courses in terms of landscape. This is largely due to the dominance of the categories, "Sandbank and water cover" (>60\%) and "Sandbanks with marsh vegetation" $(>25 \%)$, that developed on the canalised river bed after the opening of the nine dams that exist in the section analyzed.

\subsection{Waterfowl and Riparian Birds}

The three study areas are not equally important to waterfowl, as reflected in the significant differences between the mean values of abundance $(K=36.20 ; p<0.005)$ and density $(K=31.09$; $p<0.005)$. The Manzanares river maintains the largest $(a=1528.00 \pm 523.51)$ and most dense $(\mathrm{d}=222.7 \pm 94.94)$ wintering population of waterfowl, followed by the river Tagus in Talavera $(\mathrm{a}=$ $1131 \pm 859.53 ; \mathrm{d}=178.85 \pm 86.10)$ and in Toledo $(\mathrm{a}=745.33 \pm 358.04 ; \mathrm{d}=178.29 \pm 56.12)$. The river Henares was always the river course with the lowest waterfowl values, with very low global figures below 20 birds. As expected, there were no significant differences in the wintering populations at the two stretches of the Tagus analyzed $(\mathrm{D}=0.25 ; \mathrm{p}=0.2710)$. 
There was a marked variability in the density and abundance values (see Tables A5-A7). This is because the values for the month of February, quite late in winter, were included in the analysis. The highest global figures were always obtained in January: 1915 birds for the Manzanzares, 1110 birds for the Tagus in Talavera, and 915 birds for the Tagus in Toledo. The values for the river Henares are irrelevant as they never exceeded 55 birds a month.

The mean richness values were high for the river Tagus in Talavera $(r=19.67 \pm 1.53)$ and Toledo $(r=19.00 \pm 2.65)$, they were in the mid-range for the river Manzanares $(r=10.67 \pm 2.52)$, and very low for the river Henares $(\mathrm{r}<4)$. This distribution approximates very well to the $\mathrm{H}$ diversity index, although in this case the river Tagus is the river registering the highest values $(\mathrm{H}=2.06 \pm 0.24)$, which are very close to those of the river Tagus in Talavera $(\mathrm{H}=2.03 \pm 0.14)$. There is a very strong positive correlation between richness and diversity $\left(r_{s}=0.99 ; p<0.05\right)$, and a moderate positive correlation between density and diversity $\left(\mathrm{r}_{\mathrm{s}}=0.59 ; \mathrm{p}<0.05\right)$. For the river Manzanares, the high density (birds $/ \mathrm{km})$ of Chroicocephalus ridibundus $(\mathrm{d}=99.95 \pm 60.03)$, Anas platyrhynchos $(\mathrm{d}=40.38$ $\pm 4.40)$, Gallinula chloropus $(\mathrm{d}=20.85 \pm 6.35)$, and Larus fuscus $(\mathrm{d}=54.86 \pm 43.69)$ was particularly notable. For the river Tagus in Toledo, Fulica atra $(\mathrm{d}=17.92 \pm 14.38)$, Anas platyrhynchos $(\mathrm{d}=17.61$ $\pm 11.87)$, Chroicocephalus ridibundus $(\mathrm{d}=16.77 \pm 14.95)$, and Phalacrocorax carbo $(\mathrm{d}=16.93 \pm 6.49)$ were dominant. For the river Tagus in Talavera, the dominant species were Fulica atra $(\mathrm{d}=45.10 \pm$ 31.49), Phalacrocorax carbo $(\mathrm{d}=34.87 \pm 14.67)$, Anas platyrhynchos $(\mathrm{d}=26.32 \pm 16.86)$, and Chroicocephalus ridibundus $(\mathrm{d}=60,67 \mathrm{sd}>\overline{\mathrm{X}})$.

The natural and semi-natural spaces of the four fluvial territories studied host important populations of forest and marsh birds. Unlike waterfowl, there were no significant differences in the abundances of these species $(K=1331 ; \mathrm{p}>0.05)$. The maximum density values (birds/10 ha) were registered on the banks of the river Tagus in Talavera $(\mathrm{d}=240.12 \pm 80.88)$, followed by those on the banks of the river Manzanares $(d=172.64 \pm 27.11)$, the river Henares $(d=151.02 \pm 27.18)$, and the river Tagus in Toledo $(\mathrm{d}=141.16 \pm 27.11)$. The richness values range from a maximum of 28.33 species (Toledo) to a minimum of 21 species (Henares). In terms of diversity, the maximum was recorded in Talavera $(H=2.9)$ and the minimum in the river Manzanares $(H=2.44)$. These values were on the whole strongly positively correlated with the structural diversity in the areas studied $\left(\mathrm{r}_{\mathrm{s}}=0.87\right.$; $\mathrm{p}<0.05)$. The dominant species on the banks of the river Henares were Columba palumbus $(\mathrm{d}=31.29 \pm$ 8.92), Turdus merula $(\mathrm{d}=11.34 \pm 3.42)$, Erithacus rubecula $(\mathrm{d}=11.34 \pm 1.57)$, and Aegithalos caudatus $(\mathrm{d}=$ $11.79 \pm 5.66)$. Those on the banks of the river Manzanares were Columba livia domestica $(\mathrm{d}=52.75 \pm$ 11.73), Passer domesticus $(\mathrm{d}=27.79 \pm 8.67)$, Sturnus unicolor $(\mathrm{d}=9.72 \pm 6.35)$, and Pica pica $(\mathrm{d}=7.58 \pm$ 4.31). On the banks of the river Tagus in Toledo, Columba livia domestica $(\mathrm{d}=20.79 \pm 5.73)$, Columba palumbus $(\mathrm{d}=16.38 \pm 2.43)$, Passer domesticus $(\mathrm{d}=13.07 \pm 0.98)$, and Phylloscopus collybita $(\mathrm{d}=11.97 \pm$ 1.44). On the Tagus river banks in Talavera, Passer montanus $(\mathrm{d}=30.41 \pm 9.96)$, Columba palumbus $(\mathrm{d}=$ $20.87 \pm 11.91)$, Passer domesticus ( $\mathrm{d}=19.68 \pm 1.79)$, and Sturnus unicolor $(\mathrm{d}=19.08 \pm 16.91)$. In general, these are species typical of humanized environments, except for those on the banks of the Henares where forestry elements dominate.

\subsection{Sensitive Species and Habitats Included in Annex I of the Habitat Directive}

Sensitive species, according to the Annex I of the Birds Directive, represented $17.01 \%$ of the 21 species identified in the four study areas, which fall within the unfavorable or threatened SPEC category in Europe (Table 3). In addition, seven habitats were recognized as corresponding to those in Annex I of the Habitat Directive, although only three were cited in the official cartography of the Spanish Inventory of Terrestrial Habitats [77] (Table 4). 
Table 3. Protected, threatened, or declining bird species in the study areas during 2019-2020 wintering: (1) Annex I Bird Directive; (2) Status in Europe-VU Vulnerable, D Declining, and NT Near Threatened; and (3) SPEC (Species of European Conservation Concern).

\begin{tabular}{|c|c|c|c|c|}
\hline & Annex I (1) & European Status (2) & SPEC (3) & River \\
\hline \multicolumn{5}{|c|}{ Waterfowl } \\
\hline Actitis hypoleucos & & $\mathrm{D}$ & 3 & TTO, TTA \\
\hline Alcedo atthis & $*$ & $\mathrm{VU}$ & 3 & MNZ, TTO, TTA \\
\hline Aythya ferina & & VU & 1 & TTA \\
\hline Ciconia ciconia & $*$ & & & MNZ, TTO, TTA \\
\hline Circus aeroginosus & $*$ & & & TTO, TTA \\
\hline Egretta garzetta & $*$ & & & MNZ, TTO, TTA \\
\hline Fulica atra & & NT & 3 & TTO, TTA \\
\hline Gallinago gallinago & & $\mathrm{D}$ & 3 & MNZ, TTO, TTA \\
\hline Ixobrychus minutus & $*$ & & 3 & TTO TTA \\
\hline Nycticorax nycticorax & & & 3 & TTO, TTA \\
\hline Porphyrio porphyrio & $*$ & & & TTO, TTA \\
\hline Porzana porzana & $*$ & & & MNZ \\
\hline \multicolumn{5}{|c|}{ Other Species } \\
\hline Delichon urbicum & & $\mathrm{D}$ & 2 & TTA \\
\hline Hirundo rustica & & $\mathrm{D}$ & & TTA \\
\hline Passer domesticus & & $\mathrm{D}$ & 3 & HNR-MNZ-TTO-TTA \\
\hline Passer montanus & & & 3 & HNR-MNZ-TTO-TTA \\
\hline Picus sharpei & & & 1 & HNR-MNZ-TTO-TTA \\
\hline Serinus serinus & & $\mathrm{D}$ & 2 & HNR-MNZ-TTO-TTA \\
\hline Sturnus vulgaris & & & 3 & MNZ \\
\hline Troglodytes troglodytes & $*$ & & & HNR-MNZ-TTA \\
\hline Turdus iliacus & & & 1 & TTA \\
\hline
\end{tabular}

Table 4. Habitat of Annex I of the Habitat Directive and communities: [EUc] Habitat code of the European Union [69], (Sc) Spanish habitat code [77]. HRN, Henares river; MNZ, Manzanares river; TTO, Tagus river in Toledo; and TTA, Tagus river in Talavera $\left(^{*}\right)$ [78].

[EUc 3250] Constantly flowing Mediterranean rivers with Glaucium flavum

(Sc 225011) Andryaletum ragusinae Br.-Bl. \& O. Bolòs 1958: HNR, TTO, TTA.

[EUc 3280] Constantly flowing Mediterranean rivers with Paspalo-Agrostidion species and hanging curtains of Salix and Populus alba

(Sc 228012) Ranunculo scelerati-Paspaletum paspalodis Rivas Goday 1964 corr. Peinado, Bartolomé, Martínez-Parras \& Ollala 1988: HNR, MNZ, TTO, TTA.

[EUc 7210] Calcareous fens with Cladium mariscus and species of the Caricion davallianae

(Sc 621123) Reedbeds with Schoenoplectus lacustris: HNR, TTO $(*)$, TTA.

[EUc 92A0] Salix alba, Salix sp. and Populus alba galleries

(Sc 82A056) Salicetum salviifoliae Oberdorfer and Tüxen in Tüxen and Oberdorfer 1958: MNZ.

(Sc) Salicion salviifoliae Rivas-Martínez, T.E. Díaz, F. Prieto, Loidi \& Penas 1984: HNR.

[EUc 92D0] Mediterranean riparian galleries (Nerio-Tamariceteae) and south-west Iberian Peninsula riparian galleries (Securinegion tinctoriae)

(Sc 82D013) Tamarix canariensis, Tamarix gallica and Tamarix africana Grove: HNR*, TTO $\left(^{*}\right)$, TTA.

[EUc 6420] Mediterranean tall humid grasslands of the Molinio-Holoschoenion

(Sc 542015) Holoschoenetum vulgaris Br.-Bl. ex Tchou 1948: HNR, TTO, TTA

(Sc 54201P) Trifolio resupinati-Holoschoenetum Rivas Goday 1964: MZN.

[EUc 6430] Hydrophilous tall herb fringe communities of plains and of the montane to alpine level

(Sc 543135) Myrrhoidi nodosae-Alliarietum petiolatae Rivas-Martínez \& Mayor ex V. Fuente 1986. HNR, TTO, TTA.

(Sc 543110) Convolvulion sepium Tüxen 1947: HRN, TTO, TTA. 


\section{Discussion}

The recovery of river spaces in urban areas is one of the most useful tools for the conservation of biodiversity [79], particularly due to their intrinsic value and importance as a functional connector between residual natural elements. However, the treatment given to urban riverbanks, frequently proposed in terms of "restoration", does not usually consider the intrinsic value of these areas, their characteristics or their singularities. While the environmental and socio-economic objectives of any such intervention should be mutually beneficial [38], they are often disconnected.

Three of the four cases considered here are good examples of this, as they cause or will cause a high degree of artificialization and an objective loss of value in the affected river territories. Like other far-reaching interventions $[80,81]$, these have completely ignored the local river landscape, its value, dynamics, and its ecoterritorial and landscape context. Indeed, as indicated in various studies [8-84], the concept of "river restoration" is used to refer to projects of a quite diverse nature, and not always focused on their protection and improvement.

The same is true for the projects proposed for the banks of the river Henares or those of the river Tagus in Toledo and Talavera de la Reina. It is not possible that, "Respect for the natural values of the river, its fauna and flora, with the aim of safeguarding existing ecosystems and bringing them closer to their status prior to the negative man-made alterations" [85] is among the project's objectives in the case of the river Tagus in Talavera. Indeed, a substantial part of the actions considered will cause the destruction of one of the most valuable river landscapes in the centre of the Iberian Peninsula if implemented under the terms established in the proposal. Thus, as indicated previously, it is fundamental that these projects, whose principles and effects are contrary to the recovery and integration of river areas, are not formally presented as such.

The most expensive projects usually incorporate a good number of elements linked to structures that make the riverbanks and flood plains resilient and waterproof. This is the case for the "Salón fluvial", proposed for the banks of the river Tagus in Toledo, which is nothing but concrete terraces, like tiered seating, that artificially modifies the original morphology of that stretch of the river considerably. On the other hand, the four projects analyzed have the common and legitimate objective of permitting the use and enjoyment of riparian spaces by citizens. However, these projects make the conservation of space subject to this consideration, without differentiating valuable spaces that should remain inaccessible or with limited accessibility. In particular, the river Tagus projects in Talavera and Toledo serve to "thematise" the river space, with a variety of construction proposals that will stimulate activities that induce a greater influx of people, including a hostel and a restaurant in a flood zone in the case of the river Tagus in Talavera. The opening of multiple trails and of dog parks, in hitherto well-preserved river spaces, increases the risk of their degradation due to the problems derived from affluence, such as noise, garbage, and direct predation in the case of pets running around leash-free, etc.

The projects studied did not analyse or consider the value of river spaces in terms of diversity. How is it possible that projects of high environmental impact are implemented without previously determining the value of the territory affected? The sections of the river Tagus analyzed in Toledo and Talavera are areas of great interest for wintering water birds, with average densities above 140 and $240 \mathrm{birds} / \mathrm{km}$, respectively, and with high values of diversity $(\mathrm{H}>2)$. The value of the community parameters for passerine species and related communities is also very high, especially the diversity values $(\mathrm{H}>2.8)$. Both riverbanks also maintain a good number of habitats included in Annex I of the Habitats Directive, as well as rare, threatened, or sharply declining species in Europe (Figure 4), in particular Circus aeroginosus, Nycticorax nycticorax, Ixobrychus minutus, Passer montanus or Picus sharpei. 


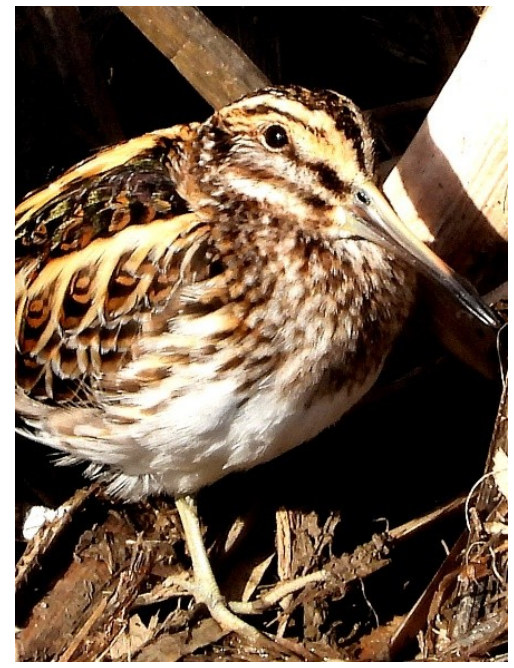

(a)

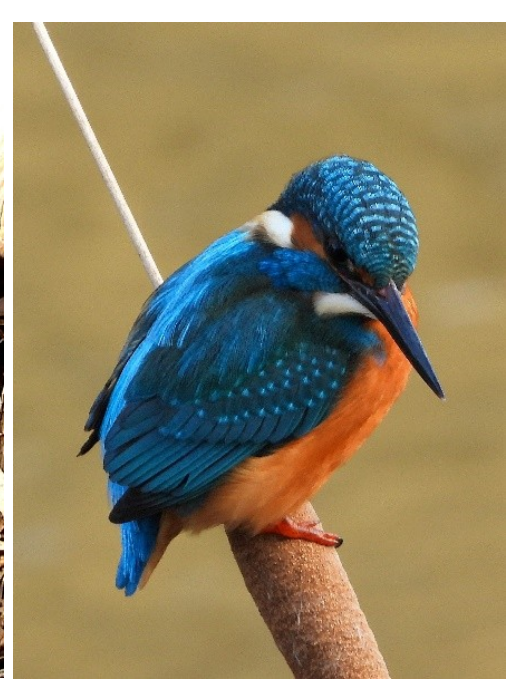

(b)

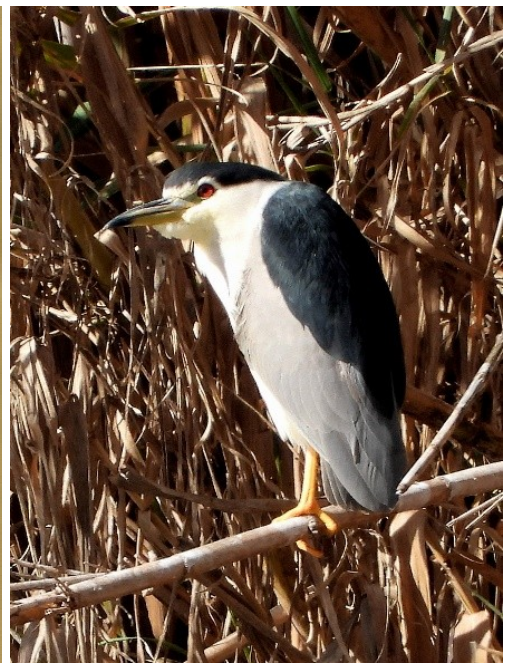

(c)



(d)

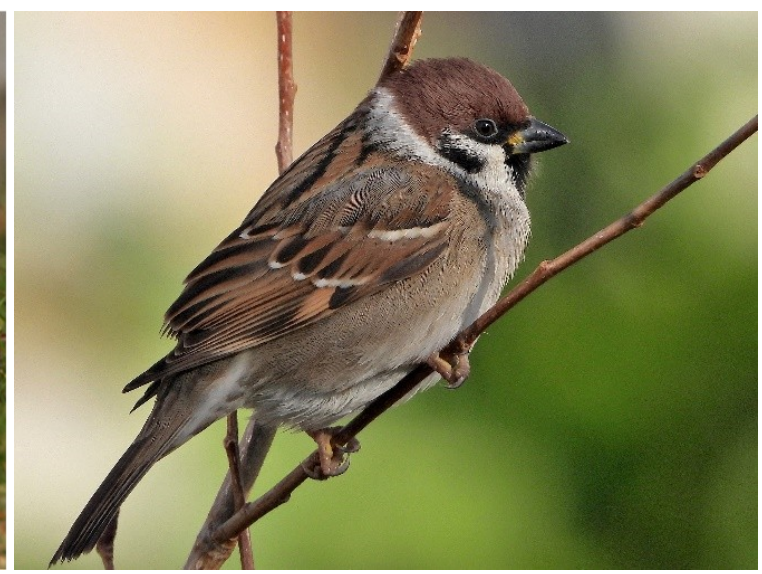

(e)

Figure 4. Some sensitive species. Above, Lymnocryptes minimus (a) (river Manzanares, 5/12/2019), Alcedo atthis (b) (river Manzanares, 26/12/2019), Nycticorax nycticorax (c) (river Tagus in Toledo, 27/2/2020). Below, Picus sharpei (d) (river Manzanares, 28/2/2020), Passer montanus (e) (river Manzanares, 26/12/2019).

In the specific case of the project developed on the banks of the river Henares (Figure 5), we were able to verify the extent of the damage caused by the implementation of the project supposedly aimed at achieving the "Recovery of the right bank of the Henares river, between the Arab bridge and the Julián Besteiro bridge", $80 \%$ co-financed, to the tune of $€ 1,150,622$, by the European Regional Development Fund under the "Operational Program for Sustainable Growth 2014-2020" [86]. Indeed, the average density values for the forest-marsh bird communities in the winter of 2019-2020 were significantly lower than those in the winter of 2013-2014, with a $45 \%$ decrease of the average values in the winter of 2019-2020. Diversity values also fell, although they were only $2.5 \%$ lower in 2019-2020 than in 2013-2014. In terms of waterfowl, despite the limited interest of this group of birds in this stretch of the river, the $60.4 \%$ drop in the figures for 2019-2020 relative to those registered in 2013-2014 is particularly striking. 


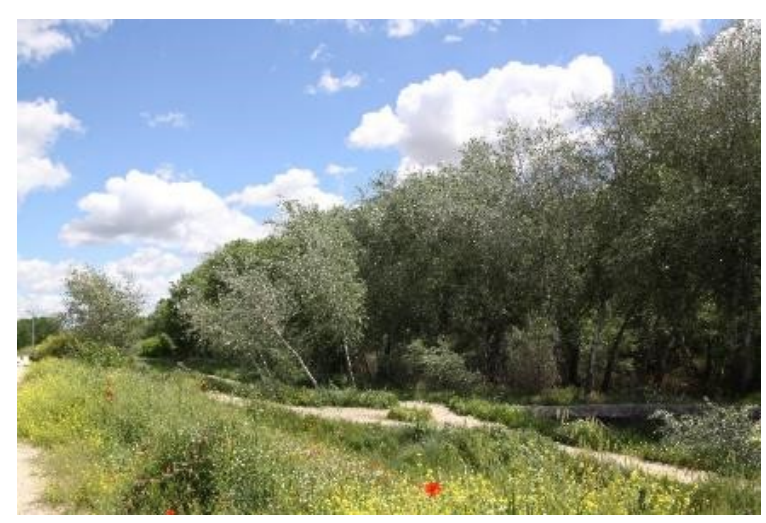

(a)

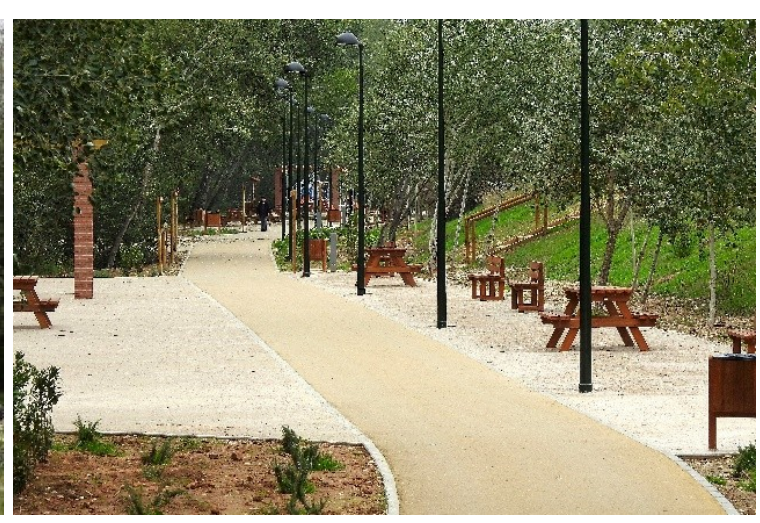

(b)

Figure 5. Bank of the river Henares before (a) (10/5/2014) and after (b) (29/10/2019) the implementation of the project over a small area of activity.

Any project whose objective is the recovery of river spaces in urban or peri-urban areas must initially locate the remnants of any existing natural landscape. The priority should be to protect these areas in order to try to extend these habitats [87], not least as they are source areas and host habitats of great value to wildlife [88]. Indeed, the rapid recovery of the river Manzanares in the city of Madrid can be largely attributed to the existence of upstream river spaces currently undergoing restoration that maintain extensive natural remnants [89]. Furthermore, the planning of this space was based on criteria of diversity, coherence, and continuity, which are basic elements to guarantee the quality of the landscape [90]. As such, a space of great value in terms of biodiversity has been created within an intensely urbanized area ex novo, and following a behavior observed in other river areas [22,91,92].

Of the four projects analyzed, only the re-naturalization of the river Manzanares meets one of the basic requirements of the Water Framework Directive: to situate environmental concerns at the centre of any interventions [93]. Of all the cases studied, this is the one that started from a more precarious environmental situation and with limitations in terms of the scope of the actions undertaken, particularly due to the physical constriction of the river space and its disconnection with its former banks and its hyporheic medium, the latter due to the burying and waterproofing of the circular M-30 urban motorway. In absolute terms, even after the re-naturalization intervention, the urban section of the river Manzanares exhibits environmental values lower than those of the other sections, which can be attributed to the limitations described above, limitations that hinder the full development of the river's natural behavior. However, the intervention has explored and taken advantage of the margins for improvement provided by this stretch of the river, resulting in an exponential increase in riparian quality. All this has been achieved at low cost and of the four actions analyzed, this action has exhibited the lowest cost per linear meter.

At present, the average wintering values of waterfowl exceed 1500 individuals and the average density of passerine and related species is 220 birds/10 ha. Both are dominant generalist species, but they also include rare, threatened, or declining common species such as the Porzana porzana, Lymnocryptes minimus or Passer montanus species. This is without doubt a good example of how an urban sector of a river of no value has become a valuable space within a city for both the birds in the river area and for ecological diversity in general, contributing to the permeation of a high-density urban space and promoting regional connectivity. Moreover, the restoration measures applied were low impact, causing a re-naturalization of a river course highly valued by society. In this respect, it is interesting to note that rivers where only mild restoration measures have been implemented and that maintain clear features of their natural state are socially more valued than artificialized rivers [94]. Furthermore, the bond established between the resident population and the restored space has a positive effect on the valuation of the new river landscape, as reported previously [95]. This may have 
occurred because thanks to its re-naturalization, this space provides new possibilities of use, as has been the case with other rivers located in high-density urban areas [96].

Another major problem with most interventions in river spaces is the consideration of these spaces as independent sectors [97]. Like all river spaces, urban river spaces must be considered as part of a complex system of interconnected units that have to be managed at both the river and drainage network level [98]. Furthermore, urban and peri-urban river landscapes can be internalised and understood as "Third Landscapes" [99]: residual spaces of high value in terms of environmental and landscape diversity, the evolution — and disappearance — of which is usually associated with urban planning and development. For this reason, it is important to highlight the need to consider principles, values, criteria, objectives, and actions that differ considerably from those usually contemplated. That is, the essence of urban and peri-urban river landscapes must be founded on an understanding of its value, dynamics, and possibilities of use. A major challenge for the conservation of urban green spaces-including river spaces-is perhaps understanding how they can be developed, remodelled or restored whilst favoring natural processes, and conserving functional ecosystems [21]. That would enhance models of intervention that often do not consider environmental improvements [100].

In the current climatic scenario, with a clear tendency towards aridity, there is a clear increase in the value of river areas as "environmental corridors". The importance of river corridors as priority elements within the "European Green Infrastructures" must also be taken into account [101]. The European proposal points out the need to improve the connectivity between natural areas, using river corridors to counteract the effects of fragmentation of these territories. In particular, there is a growing importance placed on rivers in urban and peri-urban areas to maintain biodiversity due to the steady increase in the extension of these spaces [102-104].

\section{Conclusions}

Before undertaking any actions involving urban river courses, it is essential to understand the environmental and landscape interest of the spaces under consideration. This is especially important when these interventions highlight sustainability among their objectives, and they establish "activities of environmental recovery or integration". At three of the sites analyzed in this study interventions were presented that will cause important modifications, yet the environmental interest of the areas in which they will be carried out was not analyzed. Nor was their capacity to integrate into the urban landscape evaluated. These are expensive projects, with costs lying between 900,000 and $€ 2$ million per linear km. Nevertheless, it is noteworthy that of the cases analyzed, the project that best integrated the river into the city, respecting and potentiating its natural value and interest as a landscape, is that which cost the least money: $€ 162,000$ per linear $\mathrm{km}$. Specifically, we refer to the project to recover the natural habitat of the river Manzanares in Madrid. This project set out to convert this urban fluvial stretch into an area of interest for wintering aquatic birds. It also hosts some globally threatened species and it maintains habitats that are included in Annex I of the Habitats Directive. In addition, it is also a highly valued social and leisure area for the local population.

Author Contributions: P.M.H. and A.-B.B.M.: devised the ideas for this study, collected and analyzed the data, and wrote the original manuscript; L.J.R. contributed to developing the original idea of the study and reviewed the manuscript; and F.A.Á. assisted in the data collection and analysis, and reviewed the associated literature. All authors have read and agreed to the published version of the manuscript.

Funding: This research was funded by Erasmus+ Project RailtoLand (Grant agreement: 2019-1-ES01-KA203-065554 - Erasmus+ Programme of the Europe Union).

Acknowledgments: We thank Tomás Velasco and Íñigo Vicente for their participation in the waterfowl census. Conflicts of Interest: The authors have no conflict of interests to declare. 


\section{Appendix A}

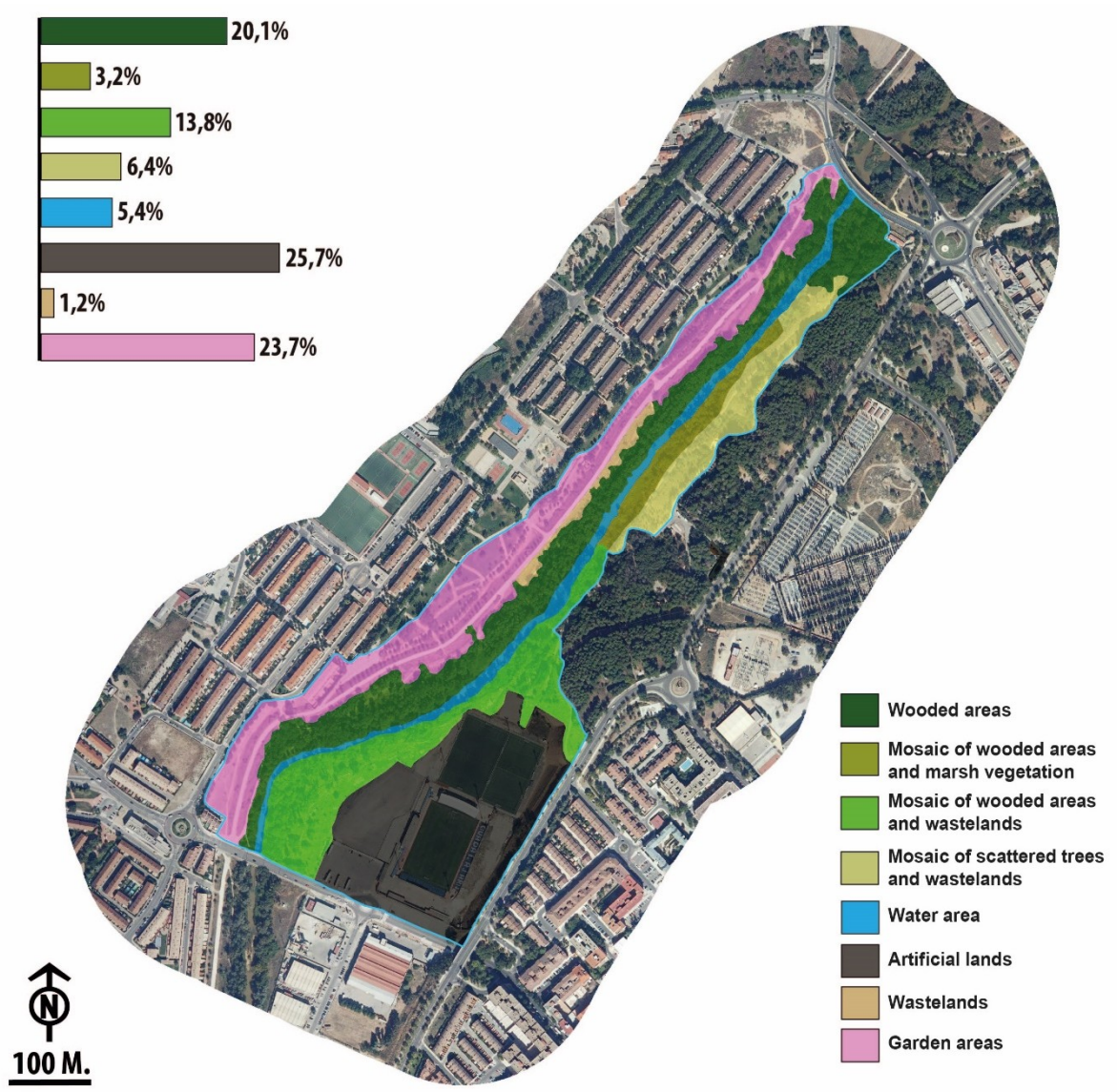

Figure A1. Landscape units for the river Henares.


(a)

Figure A2. Cont. 


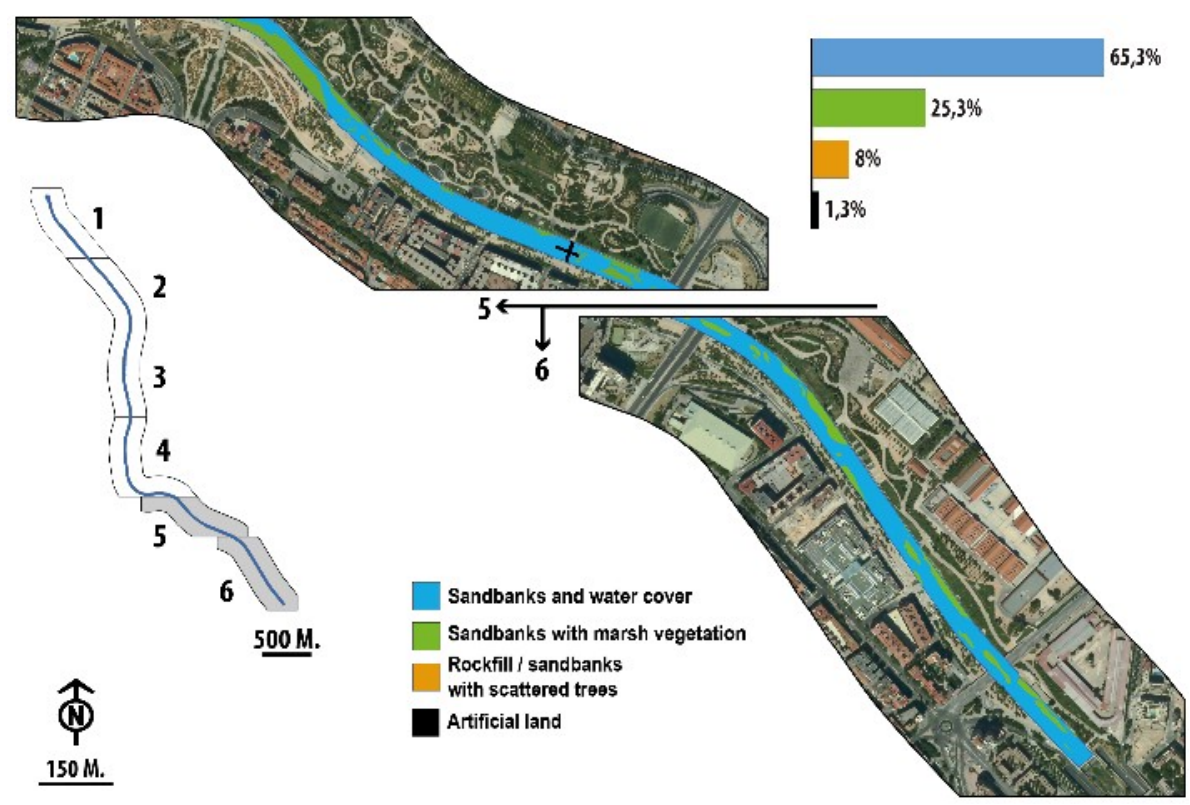

(b)

Figure A2. Landscape units for the river Manzanares (a,b).

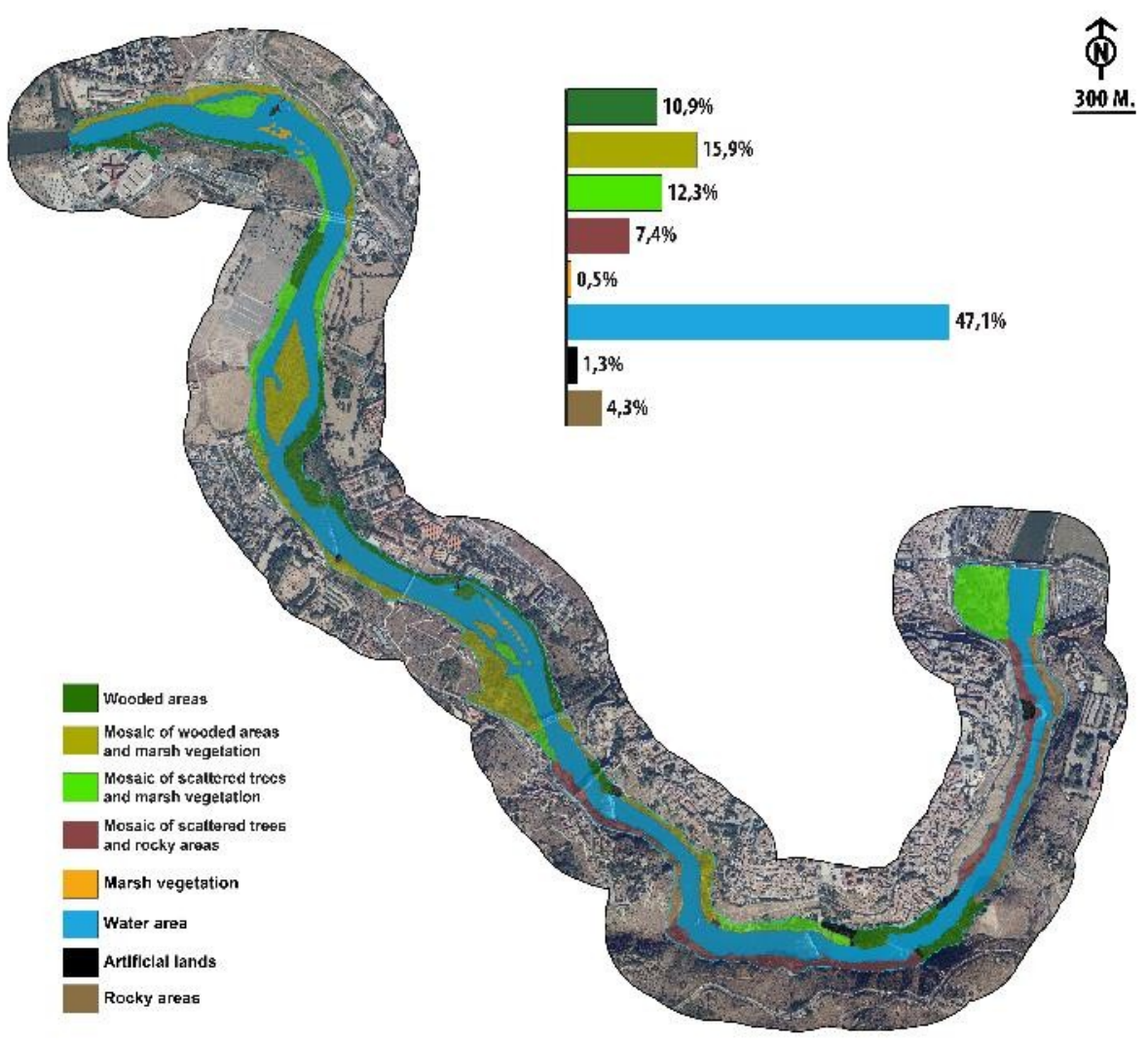

Figure A3. Landscape units for the river Tagus in Toledo. 




Figure A4. Landscape units for the Tagus river in Talavera de la Reina.

\section{Appendix B}

Table A1. Analysis of the actions on the river Manzanares.

\begin{tabular}{ll}
\hline City & Madrid \\
\hline Length & $7.5 \mathrm{~km}$; of which only $6.86 \mathrm{~km}$ are accessible \\
\hline Character & Urban \\
\hline Total cost & $€ 1,216,054$ \\
\hline Unit cost (per linear meter) & $€ 162.14 / \mathrm{m}$ \\
\hline Action status & Implemented May 2016-May 2019 \\
\hline Promoter & Madrid City Council, following a suggestion by Ecologists in Action \\
\hline Funding & Municipal budgets \\
\hline Overall aim of the action & \\
\hline
\end{tabular}

The plan aims to recover and preserve, to the extent possible, the functions of the ecological corridor that the river Manzanares defines as it passes through Madrid relative to the upper and lower sections, and to manifest its value within the urban environment, in line with the guidelines set out in the relevant European legislation (Water Framework Directive) and the National Strategy for River Restoration.

Actions with an impact on the hydrological regime and their effects

Actions:

- Opening of all the gates that regulate the water flow along the section stipulated.

Effects:

- Partial recovery of the natural sedimentation and erosion processes, as well as those of natural colonization of riparian species of flora and fauna.

- Improvement of the longitudinal continuity of flow.

Actions and Effects on the morphology of the channel and its bank

Actions:

- Partial removal of the breakwaters at the ends of the section and the conditioning of its embankment.

- Preparation of the banks employing bioengineering techniques.

- Creation of deflectors using bioengineering techniques to create a meandering river course in the central section.

Effects:

- Improvement of riparian environments.

- Improvement of the lateral connectivity of the channel with its banks.

- Landscape integration. 
Table A1. Cont.

Actions and Effects on vegetation and fauna

Actions:

- Revegetation of breakwaters.

- Planting of autochthonous species of riparian trees and shrubs (more than 5000 specimens).

- Elimination of exotic species.

- Installation of nesting boxes.

- $\quad$ Release of stripe-necked terrapin (Mauremys leprosa).

Effects:

- Increase in biodiversity as a consequence of the improvements of the riparian habitat for many species of fauna, especially birds, but also for other relevant elements like otters (Lutra lutra).

Table A2. Analysis of the actions on the river Henares in the city of Guadalajara.

\begin{tabular}{ll}
\hline City & Guadalajara \\
\hline Length & $1.47 \mathrm{~km}$ \\
\hline Character & Urban \\
\hline Total cost & $€ 1,438,277.90$ \\
\hline Unit cost (per linear meter) & $€ 978.42 / \mathrm{m}$ \\
\hline Action status & Implemented October 2018-May 2019 \\
\hline Promoter & Guadalajara City Council \\
\hline Funding & European Regional Development Fund \\
\hline Overall aim of the action &
\end{tabular}

The overall objectives included in the Strategy for the Sustainable Urban Development of Guadalajara were the:

- Creation of new spaces for leisure and recreation.

- Aesthetic improvement of the river.

- Improvement of pedestrian safety.

- Preservation of environmental conditions.

- Establishment of a new park alongside the existing one in the area known as "La Chopera".

Actions with an impact on the hydrological regime and their effects

Actions: Non-existent

Effects: -

Actions and Effects on the morphology of the channel and its bank

Actions:

- Construction of viewpoints by remodelling the terrain of the banks and advancing it towards the channel.

- Actions to compact and waterproof a trail, which will have a width of $2.5 \mathrm{~m}$ along most of the route and that runs through a Public Hydrological Domain (P.H.D.).

Effects:

- Artificialisation of the riverbank.

- Increased pedestrian traffic in the P.H.D.

- Compaction and waterproofing of part of the riverbank, which by definition is a permeable area.

- Direct effects on the riverside vegetation due to land clearing and filling in the levelling works.

Actions and effects on vegetation and fauna

Actions:

- Clearing and felling of large poplar trees on the riverbank to permit the construction of roads, parks and viewpoints.

- Installation of illumination.

Effects:

- Increase of traffic and use in the P.H.D.

- Increase in nocturnal illumination affecting the riparian fauna.

- Artificialisation of the riverbank. 
Table A3. Analysis of the actions on the Tagus river in the city of Toledo.

\begin{tabular}{ll}
\hline City & Toledo \\
\hline Length & $43 \mathrm{~km}$; of which 6.36 are in urban and peri-urban sections \\
\hline Character & Urban, peri-urban and rural \\
\hline Total cost & $€ 90,648,611.94$ \\
\hline Unit cost (per linear meter) & $€ 2108.11 / \mathrm{m}$ (although the actions focus on the urban section) \\
\hline Action status & Call for tenders pending \\
\hline Promoter & $\begin{array}{l}\text { Tagus Hydrographic Confederation, with the collaboration of the Toledo } \\
\text { City Council }\end{array}$ \\
\hline Funding & General State Budget \\
\hline
\end{tabular}

Overall aim of the action

According to the call for tenders, the overall objective was the harmonization of the urban environment of Toledo with the river environment, recovering the riverbanks and its adjacent spaces, as well as improving pedestrian connections between the city and the river.

Actions with an impact on the hydrological regime and their effects

Actions:

- Rehabilitation of historical hydraulic infrastructures.

Effects:

- Increased longitudinal fragmentation of the river.

- Possible modification of the hydraulic regime of the river channel based on the management of the infrastructure and on the final provisions laid down in the rehabilitation project.

Actions and Effects on the morphology of the channel and its bank
Actions:

- "Salón fluvial" in an urban section of 4 ha, involving terracing with concrete walls filled with earth.

- Construction of longitudinal mounds on both banks along the entire section.

- $\quad$ Opening of compacted or paved roads in riparian areas and through rarely frequented slopes.

\section{Effects:}

- Artificialisation of the river course and its bank. Waterproofing of the bank affected by the action named the "Salón fluvial".

- Loss of lateral connectivity between the river channel and its surrounding areas.

- Alteration of the natural dynamics of river flooding, avoiding the dispersion of nutrients and energy to its flood plains, increasing the flow speed and therefore, the risk of downstream flooding.

- Increase of pedestrian traffic and use in the P.H.D.

- $\quad$ Loss of landscape quality.

Actions and effects on vegetation and fauna

Actions:

- Night lighting.

Effects:

- Increase in nocturnal illumination affecting the riparian fauna. 
Table A4. Analysis of the actions on the Tagus river in Talavera de la Reina.

\begin{tabular}{ll}
\hline City & Talavera de la Reina \\
\hline Length & $14 \mathrm{~km}$; of which 4.56 are in urban sections \\
\hline Character & Urban, peri-urban and rural \\
\hline Total cost & $€ 14,033,300.00$ \\
\hline Unit cost (per linear meter) & $€ 1002.38 / \mathrm{m}$ \\
\hline Action status & Call for tenders pending \\
\hline Promoter & $\begin{array}{l}\text { Tagus Hydrographic Confederation, with the collaboration of the Talavera de la } \\
\text { Reina City Council }\end{array}$ \\
\hline Funding & General State Budget \\
\hline Overall aim of the action & \\
\hline
\end{tabular}

- To respect the natural values of the river, its fauna and flora, with the aim of safeguarding existing ecosystems and bringing them closer to their status prior to negative man-made alterations.

- To recognise the historical value of the heritage and constructions in order to avoid their deterioration through functional rehabilitation, either for their original uses or for other uses that guarantee their adequate conservation.

- To perform interventions on the banks and islands aimed at promoting the use and the enjoyment of the river, making recreational and cultural activities compatible with its natural life. A proposal for preventive measures to ensure that river does not pose a natural barrier to communications and the functioning of the city, and to mitigate the negative effects of these activities on the existing ecosystems.

- Control the flooding of various streams that are tributaries of the river Tagus.

Actions with an impact on the hydrological regime and their effects

\section{Actions:}

- Functional rehabilitation of weirs and canals associated with hydroelectric plants.

Effects:

- Increased longitudinal fragmentation of the river.

- Possible modification of the hydraulic regime of the river channel based on infrastructure management and the final provisions established in the rehabilitation project.

Actions and Effects on the morphology of the channel and its bank

\section{Actions:}

- Expansion of the sections of "La Parra" and "Cornicabral" tributary arroyos.

- Opening of paths facilitating access along the entire area of action, even to Mill Island.

- Creation of an artificial lagoon in the park used as a nursery.

Effects:

- Profound alteration of the structure and composition of the streams affected.

- Artificialisation of the river space.

- Compaction of the soil in the Public Hydrological Domain.

- Increase in the influx of passers-by and opening of large isolated spaces that have been well preserved to date.

- Alteration of the local phreatic level as a consequence of the opening of an artificial lagoon.

\section{Actions and effects on vegetation and fauna}

Actions:

- Clearing and felling of spontaneous vegetation in the urban front.

- Clearing and felling of vegetation in the "La Parra", "Cornicabral" and "La Portiña" streams.

- Selective plantation of autochthonous species.

- Access for domestic animals (canine park) and access to highly frequented spaces (restaurants; hostel, etc.).

- Installation of recreational fishing zones in protected and hitherto non-accessible areas, such as the "Charca del Cura".

Effects:

- Artificialisation of large well-preserved spaces, such as the "Isla Grande", where the construction an urban park is planned.

- Increased pressure on relevant elements of flora and fauna, as a consequence of the influx of people and predatory animals.

- $\quad$ Risk of introduction of exotic species linked to recreational fishing 


\section{Appendix C}

Table A5. Average Waterfowl Abundance ( \pm SD): HRN, River Henares; MNZ, River Manzanares; TTO, River Tagus in Toledo; and TTA, River Tagus in Talavera.

\begin{tabular}{|c|c|c|c|c|}
\hline & HNR & MNZ & TTO & TTA \\
\hline Actitis hypoleucos & & & $11 \pm 7.55$ & $7.67\left(^{*}\right)$ \\
\hline Aix galericulata & $0.33(*)$ & & & \\
\hline Alcedo atthis & & $2.00(*)$ & & $2.33(*)$ \\
\hline Alopochen aegyptiaca & & $19.33 \pm 7.09$ & $0.33\left(^{*}\right)$ & \\
\hline Anas clypeata & & & $1.33\left(^{*}\right)$ & $5.00(*)$ \\
\hline Anas crecca & & & $16.33 \pm 16.01$ & $23.33 \pm 11.72$ \\
\hline Anas platyrhynchos & $24.00 \pm 20.95$ & $277.00 \pm 30.20$ & $112.00 \pm 75.50$ & $120.00 \pm 76.86$ \\
\hline Ardea cinerea & $1.00 \pm 1.00$ & $0.67\left(^{*}\right)$ & $39.67(*)$ & $15.00 \pm 7.00$ \\
\hline Aythya ferina & & & & $1.00(*)$ \\
\hline Bubulcus ibis & & & $5.33(*)$ & $2.33(*)$ \\
\hline Cairina moschata & & $0.67 \pm 0.58$ & & \\
\hline Charadrius dubius & & & & $0.33\left(^{*}\right)$ \\
\hline Chroicocephalus ridibundus & & $685.67 \pm 411.78$ & $106.67 \pm 95.10$ & $276.67(*)$ \\
\hline Ciconia ciconia & & $1.33(*)$ & $1.67 \pm 0.58$ & $4.00 \pm 3.61$ \\
\hline Circus aeroginosus & & & $0.67 \pm 0.58$ & $0.67 \pm 0.58$ \\
\hline Egretta garzetta & & $8.67 \pm 1.15$ & $2.00 \pm 1.73$ & $2.33 \pm 1.53$ \\
\hline Fulica atra & & & $114.00 \pm 91.43$ & $205.67 \pm 143.60$ \\
\hline Gallinago gallinago & & $1.67 \pm 0.58$ & $37.33\left({ }^{*}\right)$ & $22.67\left(^{*}\right)$ \\
\hline Gallinula chloropus & $1.67 \pm 0.58$ & $143.00 \pm 43.55$ & $43.33 \pm 37.65$ & $53.67\left(^{*}\right)$ \\
\hline Ixobrychus minutus & & & $3.00 \pm 1.73$ & $3.67 \pm 1.15$ \\
\hline Larus fuscus & & $376.33 \pm 299.74$ & $101.00 \pm 92.83$ & $163.33(*)$ \\
\hline Lymnocryptes minimus & & $2.00 \pm 0.00$ & & \\
\hline Mareca strepera & & & $25.00\left({ }^{*}\right)$ & $36.33\left({ }^{*}\right)$ \\
\hline Netta rufina & & & & $0.33(*)$ \\
\hline Nycticorax nycticorax & & & $7.33 \pm 5.51$ & $7.00 \pm 6.56$ \\
\hline Podiceps cristatus & & & $1.33 \pm 1.15$ & $1.67 \pm 0.58$ \\
\hline Porphyrio porphyrio & & & $0.33(*)$ & $3.00 \pm 2.65$ \\
\hline \multicolumn{5}{|l|}{ Porzana porzana } \\
\hline Phalacrocorax carbo & $1.00\left(^{*}\right)$ & $9.00 \pm 1.00$ & $107.67 \pm 41.31$ & $159.00 \pm 66.90$ \\
\hline Rallus aquaticus & & & $1.50 \pm 0.71$ & $5.50 \pm 3.54$ \\
\hline Tachybaptus ruficollis & & & $6.00 \pm 5.29$ & $8.67 \pm 4.93$ \\
\hline Tringa ochropus & & & $1.67 \pm 1.15$ & $2.50 \pm 0.71$ \\
\hline Medium Abundance & $28 \pm 24.27$ & $1528.00 \pm 523.51$ & $745.33 \pm 358.04$ & $1131 \pm 859.53$ \\
\hline
\end{tabular}

$\left(^{*}\right)$ Standard deviation (SD) higher than the average values $(\bar{X})$. 
Table A6. Average density ( \pm SD) of Waterfowl (birds/km): HRN, River Henares; MNZ, River Manzanares; TTO, River Tagus in Toledo; and TTA, River Tagus in Talavera.

\begin{tabular}{|c|c|c|c|c|}
\hline & HNR & MNZ & TTO & TTA \\
\hline Actitis hypoleucos & & & $1.73 \pm 1.19$ & $1.68\left(^{*}\right)$ \\
\hline Aix galericulata & $0.45 \pm 0.393$ & & & \\
\hline Alcedo atthis & & $0.29\left(^{*}\right)$ & & $0.5\left(^{*}\right)$ \\
\hline Alopochen aegyptiaca & & $2.82 \pm 1.03$ & $0.05(*)$ & \\
\hline Anas clypeata & & & $0.21\left(^{*}\right)$ & $1.10\left(^{*}\right)$ \\
\hline Anas crecca & & & $2.57 \pm 2.52$ & $5.12 \pm 2.57$ \\
\hline Anas platyrhynchos & $22.7 \pm 16.1$ & $40.38 \pm 4.40$ & $17.61 \pm 11.87$ & $26.32 \pm 16.86$ \\
\hline Ardea cinerea & $1.13 \pm 0.393$ & $0.10\left(^{*}\right)$ & $6.24\left(^{*}\right)$ & $3.29 \pm 1.54$ \\
\hline Aythya ferina & & & & $0.22\left(^{*}\right)$ \\
\hline Bubulcus ibis & & & $0.84\left(^{*}\right)$ & $0.51\left(^{*}\right)$ \\
\hline Cairina moschata & & $0.10 \pm 0.08$ & & \\
\hline Charadrius dubius & & & & $0.07(*)$ \\
\hline Chroicocephalus ridibundus & & $99.95 \pm 60.03$ & $16.77 \pm 14.95$ & $60.67\left(^{*}\right)$ \\
\hline Ciconia ciconia & & $0.19 \pm 0.34$ & $0.26 \pm 0.09$ & $0.88 \pm 0.79$ \\
\hline Circus aeroginosus & & & $0.10 \pm 0.09$ & $0.15 \pm 0.13$ \\
\hline Egretta garzetta & & $1.26 \pm 0.17$ & $0.31 \pm 0.27$ & $0.51 \pm 0.33$ \\
\hline Fulica atra & & & $17.92 \pm 14.38$ & $45.10 \pm 31.49$ \\
\hline Gallinago gallinago & & $0.24 \pm 0.08$ & $5.87\left(^{*}\right)$ & $4.97\left(^{*}\right)$ \\
\hline Gallinula chloropus & $1.13 \pm 0.393$ & $20.85 \pm 6.35$ & $6.81 \pm 5.92$ & $11.77(*)$ \\
\hline Ixobrychus minutus & & & $0.47 \pm 0.27$ & $0.80 \pm 0.25$ \\
\hline Larus fuscus & & $54.86 \pm 43.69$ & $15.88 \pm 14.60$ & $11.84 \pm 10.54$ \\
\hline Lymnocryptes minimus & & $0.29 \pm 0.00$ & & \\
\hline Mareca strepera & & & $3.93\left(^{*}\right)$ & $7.97\left(^{*}\right)$ \\
\hline Netta rufina & & & & $0.07(*)$ \\
\hline Nycticorax nycticorax & & & $1.15 \pm 0.87$ & $1.54 \pm 1.44$ \\
\hline Podiceps cristatus & & & $0.21 \pm 0.18$ & $0.37 \pm 0.13$ \\
\hline Porphyrio porphyrio & & & $0.05\left(^{*}\right)$ & $0.66 \pm 0.58$ \\
\hline Porzana porzana & & $0.10 \pm 0.17$ & & \\
\hline Phalacrocorax carbo & $1.36 \pm 1.18$ & $1.31 \pm 0.15$ & $16.93 \pm 6.49$ & $34.87 \pm 14.67$ \\
\hline Rallus aquaticus & & & $0.16 \pm 0.16$ & $0.80(*)$ \\
\hline Tachybaptus ruficollis & & & $0.94 \pm 0.83$ & $1.90 \pm 1.08$ \\
\hline Tringa ochropus & & & $0.26 \pm 0.18$ & $0.37 \pm 0.33$ \\
\hline Global Average Density (birds/km) & $19 \pm 16.5$ & $222.74 \pm 94.93$ & $117.29 \pm 56.12$ & $177.85 \pm 86.10$ \\
\hline Global Average Richness & $3.67 \pm 1.53$ & $10.67 \pm 2.52$ & $19.00 \pm 2.65$ & $19.67 \pm 1.53$ \\
\hline Diversity & $0.55 \pm 0.17$ & $1.37 \pm 0.12$ & $2.06 \pm 0.14$ & $2.04 \pm 0.13$ \\
\hline
\end{tabular}

$\left(^{*}\right)$ Standard deviation $(\mathrm{SD})$ higher than the average values $(\overline{\mathrm{X}})$. 
Table A7. Average density values ( \pm SD) of Riparian birds (birds/10ha): HRN, River Henares; MNZ, River Manzanares; TTO, River Tagus in Toledo; and TTA, River Tagus in Talavera.

\begin{tabular}{|c|c|c|c|c|}
\hline & HNR & MNZ & TTO & TTA \\
\hline Aegithalos caudatus & $11.79 \pm 5.66$ & $0.78\left(^{*}\right)$ & $4.88 \pm 1.19$ & $16.10 \pm 4.73$ \\
\hline Carduelis carduelis & & $1.46\left(^{*}\right)$ & $4.25 \pm 2.95$ & $10.14 \pm 2.73$ \\
\hline Certhia brachydactyla & $4.5 \pm 2.08$ & $1.17 \pm 0.77$ & $0.95 \pm 0.00$ & $5.96 \pm 2.07$ \\
\hline Cettia cetti & $9.07 \pm 3.42$ & $5.63 \pm 1.94$ & $7.88 \pm 2.89$ & $4.77 \pm 5.47$ \\
\hline Chloris chloris & & & $1.89 \pm 1.89$ & $3.58 \pm 3.58$ \\
\hline Cisticola juncidis & & & $0.47 \pm 0.00$ & \\
\hline Coccothraustes coccothraustes & & & $0.32(*)$ & $11.33 \pm 3.72$ \\
\hline Columba livia & & $52.75 \pm 11.73$ & $20.79 \pm 5.73$ & \\
\hline Columba oenas & $6.80(*)$ & & & \\
\hline Columba palumbus & $31.29 \pm 8.92$ & $4.76\left(^{*}\right)$ & $16.38 \pm 2.43$ & $20.87 \pm 11.91$ \\
\hline Corvus monedula & & $0.39 \pm 0.34$ & & \\
\hline Cyanistes caeruleus & $6.35 \pm 5.50$ & $3.21 \pm 0.87$ & $10.24 \pm 0.27$ & $12.52 \pm 4.73$ \\
\hline Delichon urbicum & & & $\left.0.79{ }^{*}\right)$ & $\left.2.39{ }^{*}\right)$ \\
\hline Dendrocopos major & $1.81 \pm 0.79$ & $\left.0.29{ }^{*}\right)$ & $0.16\left(^{*}\right)$ & $\left.1.19{ }^{*}\right)$ \\
\hline Dryobates minor & & & & $1.79 \pm 0.00$ \\
\hline Emberiza cirlus & $0.68\left(^{*}\right)$ & & & \\
\hline Emberiza schoenichlus & & $0.10(*)$ & & \\
\hline Erithacus rubecula & $11.34 \pm 1.57$ & $3.30 \pm 1.71$ & $2.84 \pm 1.70$ & $7.75 \pm 2.73$ \\
\hline Fringilla coelebs & $1.36 \pm 1.36$ & $\left.0.10{ }^{*}\right)$ & $2.99 \pm 1.36$ & $6.56 \pm 2.73$ \\
\hline Hirundo rustica & & & & $3.46 \pm 1.65$ \\
\hline Motacilla alba & $1.81 \pm 0.79$ & $7.48 \pm 3.38$ & $0.95 \pm 0.00$ & $2.39 \pm 1.03$ \\
\hline Motacilla cinerea & $0.45\left(^{*}\right)$ & $1.65 \pm 0.89$ & $0.47 \pm 0.47$ & $2.39 \pm 1.03$ \\
\hline Myiopsitta monachus & & $4.08 \pm 1.05$ & & $1.79\left(^{*}\right)$ \\
\hline Parus major & $4.99 \pm 0.79$ & $0.68\left(^{*}\right)$ & $5.20 \pm 1.25$ & $10.14 \pm 4.13$ \\
\hline Passer domesticus & $0.9\left(^{*}\right)$ & $27.79 \pm 8.67$ & $13.07 \pm 0.98$ & $19.68 \pm 1.79$ \\
\hline Passer hispaniolensis & $0.45\left(^{*}\right)$ & & $2.52 \pm 1.44$ & \\
\hline Passer montanus & $4.54\left(^{*}\right)$ & $11.17 \pm 3.98$ & $7.88 \pm 5.44$ & $30.41 \pm 9.96$ \\
\hline Periparus ater & $0.91\left(^{*}\right)$ & $2.14 \pm 1.50$ & & \\
\hline Phoenicurus ochruros & & $1.46 \pm 1.34$ & $0.95 \pm 0.00$ & $1.79 \pm 0.00$ \\
\hline Phylloscopus collybita & $7.26 \pm 5.50$ & $7.48 \pm 4.38$ & $11.97 \pm 1.44$ & $10.14 \pm 2.73$ \\
\hline Pica pica & $7.71 \pm 6.28$ & $7.58 \pm 4.31$ & $2.05 \pm 0.27$ & $2.39 \pm 1.03$ \\
\hline Picus sharpei & $0.45\left(^{*}\right)$ & $1.07 \pm 1.02$ & $0.47 \pm 0.00$ & $0.60\left(^{*}\right)$ \\
\hline Prunella modularis & $0.91(*)$ & $0.58\left(^{*}\right)$ & $0.16\left(^{*}\right)$ & \\
\hline Psittacula krameri & & $0.29 \pm 0.29$ & & \\
\hline Ptyonoprogne ruspestris & & $4.66\left(^{*}\right)$ & & \\
\hline Regulus ignicapillus & & $0.10\left(^{*}\right)$ & & \\
\hline Remiz pendulinus & $1.36(*)$ & & $0.32(*)$ & \\
\hline Serinus serinus & $6.35\left(^{*}\right)$ & $3.40\left(^{*}\right)$ & $5.67 \pm 1.89$ & $13.12 \pm 7.23$ \\
\hline
\end{tabular}


Table A7. Cont.

\begin{tabular}{|c|c|c|c|c|}
\hline & HNR & MNZ & TTO & TTA \\
\hline Spinus spinus & & $0.19\left(^{*}\right)$ & & \\
\hline Streoptopelia decaocto & $3.17 \pm 1.57$ & & $0.16\left(^{*}\right)$ & $3.58 \pm 3.58$ \\
\hline Sturnus unicolor & $6.80 \pm 2.72$ & $9.72 \pm 6.35$ & $2.68 \pm 0.72$ & $19.08 \pm 16.91$ \\
\hline Sturnus vulgaris & & $0.10\left(^{*}\right)$ & & \\
\hline Sylvia atricapilla & $0.45\left(^{*}\right)$ & $0.39 \pm 0.17$ & $3.78 \pm 1.25$ & $1.79 \pm 1.79$ \\
\hline Sylvia melanocephala & & $0.19\left(^{*}\right)$ & $0.79 \pm 0.27$ & \\
\hline Troglodytes troglodytes & $3.17 \pm 0.79$ & $0.29 \pm 0.29$ & & $0.60\left(^{*}\right)$ \\
\hline Turdus iliacus & $0.45\left(^{*}\right)$ & & & \\
\hline Turdus merula & $11.34 \pm 3.42$ & $6.22 \pm 3.37$ & $5.99 \pm 0.55$ & $12.52 \pm 1.79$ \\
\hline Turdus philomelos & $2.72 \pm 2.36$ & & $1.26 \pm 0.27$ & $1.19\left(^{*}\right)$ \\
\hline Upupa epops & & & $0.16\left(^{*}\right)$ & $0.60\left(^{*}\right)$ \\
\hline $\begin{array}{l}\text { Global Average Density } \\
\text { (birds/10ha) }\end{array}$ & $151.02 \pm 27.18$ & $172.64 \pm 27.11$ & $141.16 \pm 8.74$ & $240.12 \pm 80.88$ \\
\hline Global Average Richness & $21 \pm 1.73$ & $27 \pm 0.47$ & $28.33 \pm 2.49$ & $24.67 \pm 2.49$ \\
\hline Diversity & $2.65 \pm 0.48$ & $2.44 \pm 0.13$ & $2.86 \pm 0.09$ & $2.90 \pm 0.09$ \\
\hline
\end{tabular}

$\left(^{*}\right)$ Standard deviation $(\mathrm{SD})$ higher than the average values $(\overline{\mathrm{X}})$.

\section{References}

1. Nilsson, C.; Reidy, C.A.; Dynesius, M.; Revenga, C. Fragmentation and flow regulation of the world's large river systems. Science 2005, 308, 405. [CrossRef]

2. Paul, M.J.; Meyer, J.L. Streams in the urban landscape. Annu. Rev. Ecol. Syst. 2001, 32, 333-365. [CrossRef]

3. Tockner, K.; Stanford, J.A. Riverine flood plains: Present state and future trends. Environ. Conserv. 2002, 29, 308-330. [CrossRef]

4. Walsh, C.J.; Roy, A.H.; Feminella, J.W.; Cottingham, P.D.; Groffman, P.M.; Morgan, R.P. The urban stream syndrome Current knowledge and the search for a cure. J. N. Am. Benthol. Soc. 2005, 24, 706-723. [CrossRef]

5. Petts, G.E.; Heathcote, J.; Martin, D. Urban Rivers: Our Inheritance and Future; IWA Publishing/Environment Agency: London, UK, 2002; p. 117.

6. Wozniak, M.; Leuven, R.S.E.W.; Lenders, H.J.R.; Chmielewski, T.J.; Geerling, G.W.; Smits, A.J.M. Assessing landscape change and biodiversity values of the Middle Vistula river valley, Poland, using BIO-SAFE. Landsc. Urban. Plan. 2009, 92, 210-219. [CrossRef]

7. Grill, G.; Lehner, B.; Thieme, M.; Geenen, B.; Tickner, D.; Antonelli, F.; Zarfl, C. Mapping the world's free-flowing rivers. Nature 2019, 569, 215-221. [CrossRef] [PubMed]

8. Blanton, P.; Marcus, W.A. Railroads, roads and lateral disconnection in the river landscapes of the continental United States. Geomorphology 2009, 112, 212-227. [CrossRef]

9. Berrocal-Menárguez, A.B.; Molina-Holgado, P. El valor de los paisajes fluviales: Su consideración en la planificación y la normativa. Planur-E 2009, 6, 4.

10. Everard, M.; Moggridge, H.L. Rediscovering the value of urban rivers. Urban. Ecosyst. 2012, 15, $293-314$. [CrossRef]

11. Gurnell, A.; Lee, M.; Souch, C. Urban rivers: Hydrology, geomorphology, ecology and opportunities for change. Geogr. Compass 2007, 1, 1118-1137. [CrossRef]

12. Ribas, A. Los paisajes del agua como paisajes culturales: Conceptos, métodos y experiencias prácticas para su interpretación y visualización. Apogeo 2007, 32, 39-48.

13. Naiman, R.J.; Decamps, H.; Pollock, M. The Role of Riparian Corridors in Maintaining Regional. Biodiversity. Ecol. Appl. 1993, 3, 209-212. [CrossRef]

14. Martínez de Pisón, E. Valores e identidades. In El Paisaje: Valores E Identidades; Martínez de Pisón, E., Ortega, N., Eds.; Universidad Autónoma de Madrid-Fundación Duques de Soria: Madrid, Spain, 2010; pp. 11-46. 
15. Cornelis, J.; Hermy, M. Biodiversity relationships in urban and suburban parks in Flanders. Landsc. Urban. Plan. 2004, 69, 385-401. [CrossRef]

16. Ives, C.D.; Lentini, P.E.; Threlfall, C.G.; Karen Ikin, K.; Danielle, F.; Shanahan, D.F.; Garrard, G.E.; Bekessy, S.A.; Fuller, R.A.; Laura Mumaw, L.; et al. Cities are hotspots for threatened species. Glob. Ecol. Biogeogr. 2016, 25, 117-126. [CrossRef]

17. Haase, D. Urban Ecology of Shrinking Cities: An Unrecognized Opportunity? Nat. Cult. 2008, 3, 1-8. [CrossRef]

18. Crane, P.; Kinzig, A. Nature in the Metropolis. Science 2005, 308, 1225. [CrossRef] [PubMed]

19. Millard, A. Semi-natural vegetation and its relationship to designated urban green space at the landscape scale in Leeds, UK. Landsc. Ecol. 2008, 23, 1231-1241. [CrossRef]

20. Pennington, D.N.; Blair, R. Habitat selection of breeding riparian birds in an urban environment: Untangling the relative importance of biophysical elements and spatial scale. Divers. Distrib. 2011, 17, 506-518. [CrossRef]

21. Blair, R.B. Land-use and avian species diversity along an urban gradient. Ecol. Appl. 1996, 6, 506-519. [CrossRef]

22. Dallimer, M.; Rouqette, J.R.; Skinner, A.M.; Armsworth, P.R.; Maltby, L.M.; Warren, P.H.; Gaston, K.J. Contrasting patterns in species richness of birds, butterflies and plants along riparian corridors in an urban landscape. Divers. Distrib. 2012, 18, 742-753. [CrossRef]

23. Rodewald, A.D.; Bakermans, M.H. What is the appropriate paradigm for riparian forest conservation? Biol. Conserv. 2006, 128, 193-200. [CrossRef]

24. Rottenborn, S.C. Predicting the impacts of urbanization on riparian bird communities. Biol. Conserv. 1999, 88, 289-299. [CrossRef]

25. Suri, J.; Anderson, P.M.; Charles-Dominique, T.; Hellard, E.; Cumming, G.S. More than just a corridor: A suburban river catchment enhances bird functional diversity. Landsc. Urban. Plan. 2017, 157, 331-342. [CrossRef]

26. Andrade, R.; Bateman, H.L.; Frank, J.; Allen, D. Waterbird community composition, abundance, and diversity along an urban gradient. Landsc. Urban. Plan. 2018, 170, 103-111. [CrossRef]

27. Säumel, I.; Kowarik, I. Urban rivers as dispersal corridors for primarily wind-dispersed invasive tree species. Landsc. Urban. Plan. 2010, 94, 244-249. [CrossRef]

28. Aguiar, F.C.F.; Ferrereira, M.T. Plant invasions in the rivers of the Iberian Peninsula, south-western Europe: A review. Plant. Biosyst. 2013, 147, 1107-1119. [CrossRef]

29. Bravard, J.P. La gestión de los ríos en el medio urbano: Tendencias francesas. In Ríos Y Ciudades; De la Call, P., Pellicer, F., Eds.; Institución Fernando El Católico: Zaragoza, Spain, 2002; 400p.

30. Inoue, M.; Nakagoshi, N. The effects of human impact on spatial structure of the riparian vegetation along the Ashida river, Japan. Landsc. Urban. Plan. 2001, 53, 111-121. [CrossRef]

31. Dearborn, C.C.; Kark, S. Motivations for Conserving Urban Biodiversity. Conserv. Biol. 2010, 24, 432-440. [CrossRef]

32. Molina, P.; Berrocal, A. Dinámica fluvial, propiedad de la tierra y conservación del paisaje de ribera en el entorno de Aranjuez (Madrid, Toledo). Estud. Geográficos 2013, 64, 495-522. [CrossRef]

33. González, M.A.; de la Lastra, I.; Rodríguez, I. La urbanización y su efecto en los ríos. In Mesa de Trabajo Estrategia Nacional de Restauración de Ríos y Riberas; Ministerio de Medio Ambiente y Universidad Politécnica de Madrid: Madrid, Spain, 2007; 45p.

34. United Nations, Department of Economic and Social Affairs. Population Division. In World Urbanization Prospects: The 2018 Revision (ST/ESA/SER.A/420); United Nations: New York, NY, USA, 2019.

35. Bayona, J.; Pujadas, I. Las grandes áreas metropolitanas en España: Del crecimiento y la expansión residencial al estancamiento poblacional. Doc. D'anàlisi Geogràfica 2020, 66, 27-55. [CrossRef]

36. Eurostat. Eurostat Regional Yearbook; European Union: Luxembourg, 2019.

37. Major Metropolitan Areas in Europe. Available online: http://www.newgeography.com/content/003879major-metropolitan-areas-europe (accessed on 9 April 2020).

38. Cengiz, B. Urban river landscapes. In Advances in Landscape Architecture; Ozyavuz, M., Ed.; InTech: Rijeka, Croatia, Yugoslavia, 2013. 
39. Vadillo, A.; Molina, P. Los paisajes del río Pisuerga en la ciudad de Valladolid: Evolución, sostenibilidad y participación ciudadana. In Colloque International Paysages de la Vie Quotidienne. Regards Croisés Entre la Recherche et L'action; CEMEGRAF: Perpignan, France, 2011; 39p.

40. Hale, B.W.; Adams, M.S. Ecosystem management and the conservation of river -floodplain systems. Landsc. Urban. Plan. 2007, 80, 23-33. [CrossRef]

41. Molina, P.; Sanz, C.; Mata-Olmo, R. Los Paisajes del Tajo; Ministerio de Agricultura, Pesca y Alimentación: Madrid, Spain, 2010; p. 358.

42. Anuario de Aforos 2015-2016. Available online: http://ceh-flumen64.cedex.es/anuarioaforos/default.asp (accessed on 20 March 2020).

43. Molina-Holgado, P. Análisis y Comparación de la Vegetación de las Riberas de los Ríos Ebro, Tajo Y Jarama. Ph.D. Thesis, Universidad Autónoma de Madrid, Madrid, Spain, 2003.

44. Biodiversity Strategy. Available online: https://ec.europa.eu/environment/nature/biodiversity/strategy/ index_en.htm (accessed on 10 December 2019).

45. The European Landscape Convention. Available online: https://www.coe.int/en/web/landscape (accessed on 10 December 2019).

46. The EU Strategy on Green Infrastructure. Available online: https://ec.europa.eu/environment/nature/ ecosystems/strategy/index_en.htm (accessed on 10 April 2020).

47. Real Decreto Legislativo 1/2001, de 20 de Julio, por el que se Aprueba el Texto Refundido de la Ley de Aguas. Available online: https://www.boe.es/buscar/act.php?id=BOE-A-2001-14276 (accessed on 5 September 2019).

48. De Castro, M.; Martín-Vide, J.; Alonso, S. El clima de España: Pasado, presente y escenarios de clima para el siglo XXI. In Evaluación Preliminar de los Impactos en España por Efecto del Cambio Climático; Moreno-Rodríguez, J.M., Ed.; Ministerio de Medio Ambiente: Madrid, Spain, 2005.

49. Alonso-Zarza, A.M. Cuenca del Tajo. In Geología de España; Vera, J., Ed.; Instituto Geológico y Minero de España: Madrid, Spain, 2004.

50. Solís, E.; Ureña, J.M.; Ruiz-Apilánez, B. Transformación del sistema urbano-territorial en la región central de la España peninsular: La emergencia de la región metropolitana policéntrica madrileña. Scr. Nova. 2012, 16. Available online: https://www.ub.edu/geocrit/sn/sn-420.htm (accessed on 10 December 2019).

51. Instituto Nacional de Estadística. Cifras Oficiales de Población Resultantes de la Revisión del Padrón Municipal A 1 de Enero 2019. Available online: https://www.ine.es/dynt3/inebase/es/index.htm?padre=517\& capsel=525 (accessed on 10 December 2019).

52. De Coca, J.; Fernández, F. La renovación del Manzanares: Transformaciones y reciclaje. Paisajes urbanos. Proy. Prog. Arquit. 2011, 4, 88-105.

53. Belinches, A. Aquitectura de Madrid; Fundación COAM: Madrid, Spain, 2003.

54. Zona de Especial Conservación Ribera de Henares ES4240003. Available online: https://www.castillalamancha. es/gobierno/agrimedambydesrur/estructura/dgapfyen/rednatura2000/zecES4240003 (accessed on 25 February 2020).

55. Instituto Geológico Y Minero de España. Navegador de Información Espacial. Available online: http: //info.igme.es/visorweb (accessed on 24 February 2020).

56. Méndez-Cabezas, M. Los Molinos de Agua de la Provincia de Toledo; Diputación Provincial de Toledo: Toledo, Spain, 1989.

57. Masa, F. Provincia de Toledo. In Guía de Castilla-La Mancha. Patrionio Histórico; Lara, P., Masa, F., Eds.; Servicio de Publicaciones de la Junta de Comunidades de Castilla-La Mancha: Toledo, Spain, 1992.

58. World Heritage List. Historical City of Toledo. Available online: https://whc.unesco.org/en/list/379 (accessed on 26 February 2020).

59. Instituto Nacional de Estadística. Viajeros Y Pernoctaciones por Puntos Turísticos. Toledo. Available online: https://www.ine.es/jaxiT3/Datos.htm?t=2078\#!tabs-tabla (accessed on 26 February 2020).

60. Pacheco, C. Obras públicas en Talavera de la Reina: Los puentes medievales. Aproximación histórica y arqueológica. Espac. Tiempo Y Forma 2001, 14, 163-191.

61. Bibby, C.J.; Burguess, N.D.; Hill, D.A.; Mustoe, S.H. Bird Census Techniques; Academic Press: London, UK, 2000.

62. Delany, S. Guidance on Waterbird Monitoring Methodology: Field Protocol for Waterbird Counting. Wetlands International: Wageningen, The Netherland, 2010.

63. Magurran, A.E. Ecological Diversity and Its Measurement; Coom Helm: London, UK, 1988. 
64. Staneva, A.; Burfield, I. European Birds of Conservation Concern. Populations, Trends and National Responsibilities; Bird Life International: Cambridge, UK, 2017.

65. IUCN. IUCN Red List Categories and Criteria, 2nd ed.; IUCN: Gland, Switzerland; Cambridge, UK, 2012.

66. Red List for Birds, Bird Life International. Available online: http://datazone.birdlife.org/spe-cies/search (accessed on 3 April 2020).

67. European Red List of Birds, Bird Life International. Office for Official Publications of the European Communities: Luxembourg. Available online: http://datazone.birdlife.org/info/euroredlist (accessed on 3 April 2020).

68. Bird Species of Annex I of the Birds Directive. Available online: https://ec.europa.eu/environment/nature/ conservation/wildbirds/threatened/index_en.htm (accessed on 4 April 2020).

69. The Habitat Directive. Available online: https://ec.europa.eu/environment/nature/legislation/ habitatsdirective/index_en.htm (accessed on 4 April 2020).

70. Plan de Naturalización del Manzanares a su paso por la Ciudad de Madrid. Available online: https: //www.esmadrid.com/sites/default/files/dossier_plan_naturalizacion_manzanares.pdf (accessed on 7 April 2020).

71. Documento Inicial Para el Procedimiento de Evaluación de Impacto Ambiental del Proyecto para la Integración del río Tajo en la Ciudad de Toledo. Available online: https://realacademiatoledo.es/wp-content/ uploads/2014/05/noticias_2014_proyectotajo2.pdf (accessed on 7 April 2020).

72. Estrategia de Desarrollo Urbano Sostenible de la Ciudad de Guadalajara. Available online: https://www.guadalajara.es/recursos/doc/portal/2017/09/19/estrategia-de-desarrollo-urbano-sostenibleintegrado-2014-2020.pdf (accessed on 7 April 2020).

73. Memoria Y Presentación de la Propuesta Técnica Ganadora del Concurso Internacional de Ideas Para la Integración de los ríos Tajo Y Alberche en la Ciudad de Talavera de la Reina. Available online: http: //www.chtajo.es/Servicios/Contratacion/Documents/talavera/MEMORIA\%20GLOBAL.pdf (accessed on 7 April 2020).

74. News in Relationship of Henares' Project. Available online: https://www.eldiario.es/clm/destrozo-Henaresambiental-Ayuntamiento-Guadalajara_0_868263921.html (accessed on 7 April 2020).

75. Consultations to the European Parliament, E-005479-18. Available online: https://www.europarl.europa.eu/ doceo/document/E-8-2018-005479_ES.html (accessed on 7 April 2020).

76. News Article in El País. La Inesperada Recuperación Medioambiental del Manzanares. Available online: https://elpais.com/ccaa/2018/09/14/madrid/1536928384_530297.html (accessed on 7 April 2020).

77. Morillo, C. Atlas Y Manual de los Hábitats Terrestres de España; Ministerio de Medio Ambiente: Madrid, Spain, 2003.

78. Hábitats de Interés Comunitario del Anexo I de la Directiva 92/43/CEE. Available online: https://www.miteco. gob.es/es/biodiversidad/servicios/banco-datos-naturaleza/informacion (accessed on 25 March 2020).

79. Franz, K.W.; Romanowski, J.; Saavedra, D. Effects of prospective landscape changes on species viability in Segre River valley, NE Spain. Landsc. Urban. Plan. 2011, 100, 242-250. [CrossRef]

80. Perini, K. Strategies and Techniques. In Sustainability and River Restoration: Green and Blue Infrastructure; Perini, K., Sabbion, P., Eds.; John Wiley \& Sons Ltd.: Madrid Río, Spain, 2016; pp. 117-126.

81. Garrido, G. Madrid Río, o el retorno de la urbe a la geografía del Manzanares. Revista PH 2017, 91, $100-117$. [CrossRef]

82. Chin, A.; Gregory, K. From research to application: Management implications from studies of urban river channel adjustment. Geogr. Compass 2009, 3, 297-328. [CrossRef]

83. Downs, P.; Gregory, K. River Channel Management: Towards Sustainable Catchment Hydrosystems; Routledge: Cambridge, UK, 2014.

84. Díaz-Orueta, U. Megaproyectos urbanos y modelo de ciudad. El ejemplo de Madrid Río. Cuaderno urbano. Espac. Cult. Soc. 2015, 19, 179-200.

85. Proyecto de Integración de los Ríos Tajo y Alberche en Talavera de la Reina. Available online: http: //www.chtajo.es/Servicios/Contratacion/Paginas/Talavera2.aspx (accessed on 10 March 2020).

86. Crecimiento Sostenible FEDER 2014-20 PO. Available online: https://www.idae.es/uploads/documentos/ documentos_PO_CrecimientoSostenible_FEDER_2014-2020_cb50c638.pdf (accessed on 10 April 2020).

87. Baschak, L.A.; Brown, R.D. An ecological framework for the planning, design and management of urban river greenways. Landsc. Urban. Plan. 1995, 33, 211-225. [CrossRef] 
88. Fujihara, M.; Kikuchi, T. Changes in the landscape structure of the Nagara River Basin, central Japan. Landsc. Urban. Plan. 2005, 70, 271-281. [CrossRef]

89. Magdaleno, F.; Fernández-Yuste, J.A.; Martínez-Santa-María, C.; Sánchez, F.J.; Aparicio, M. De Madrid al cielo a través del Manzanares: Restauración del río en el entorno de El Pardo. In Proceedings of the $6^{\circ}$ Congreso Forestal Español, Vitoria-Gasteiz, Spain, 10-14 June 2013.

90. Kuiper, J. Landscape quality based upon diversity, coherence and continuity Landscape planning at different planning-levels in the River area of The Netherlands. Landsc. Urban. Plan. 1998, 43, 91-104. [CrossRef]

91. Donnelly, R.; Marzluff, J.M. Importance of reserve size and landscape context to urban bird conservation. Conserv. Biol. 2004, 18, 733-745. [CrossRef]

92. McKinney, R.A.; Raposa, K.B.; Cournoyer, R.M. Wetlands as habitat in urbanising landscapes: Patterns of bird abundance and occupancy. Landsc. Urban. Plan. 2011, 100, 144-152. [CrossRef]

93. Hering, D.; Borja, A.; Carstensen, J.; Carvalho, L.; Elliott, M.; Feld, C.K.; Heiskanen, A.-S.; Johnson, R.K.; Moe, J.; Pont, D.; et al. The European Water Framework Directive at the age of 10: A critical review of the achievements with recommendations for the future. Sci. Total Environ. 2010, 408, 4007-4019. [CrossRef] [PubMed]

94. Junker, B.; Buchecker, M. Aesthetic preferences versus ecological objectives in river restorations. Landsc. Urban. Plan. 2008, 85, 141-154. [CrossRef]

95. Verbrugge, L.; Born, R.V.D. The role of place attachment in public perceptions of a re-landscaping intervention in the river Waal (The Netherlands). Landsc. Urban. Plan. 2018, 177, 241. [CrossRef]

96. Chou, R.J. Achieving Successful River Restoration in Dense Urban Areas: Lessons from Taiwan. Sustainability 2016, 8, 1159. [CrossRef]

97. Shi, S.; Kondolf, M.L.D. Urban River Transformation and the Landscape Garden City Movement in China. Sustainability 2018, 10, 4103. [CrossRef]

98. Landon, N.; Piégay, H.; Bravard, J.P. The Drome river incision (France): From assessment to management. Landsc. Urban. Plan. 1998, 43, 119-131. [CrossRef]

99. Clément, G. Manifiesto por el Tercer Paisaje; Gustavo Gili: Barcelona, Spain, 2018.

100. Francis, A. Urban rivers: Novel ecosystems, new challenges. Wires Water 2013, 1, 19-29. [CrossRef]

101. Green Infrastructure: Better Living through Nature-Based Solutions. Available online: https://www.eea. europa.eu/articles/green-infrastructure-better-living-through (accessed on 10 March 2020).

102. Fernández-Juricic, E.; Jokimäki, J. A habitat island approach to conserving birds in urban landscapes: Case studies from southern and northern Europe. Biodivers. Conserv. 2001, 10, 2023-2043. [CrossRef]

103. Urueña, J.M. La ordenación de los espacios fluviales en las ciudades. In Ríos y Ciudades; De la Call, P., Pellicer, F., Eds.; Institución Fernando El Católico: Zaragoza, Spain, 2002; 400p.

104. Spirn, A.W. O Jardim de Granito: A Natureza no Desenho da Cidade; Editora da Universidade de São Paulo: São Paulo, Brazil, 1995; p. 345. 